\title{
Mapping of Flood Zones in Urban Areas through a Hydro-climatic Approach: the Case of the City of Abha
}

\author{
Allaoua Ansar ${ }^{1}$ and Azaiez Naima ${ }^{1,2,3}$ \\ ${ }^{1}$ King Khalid University, Faculty of Human Sciences, Geography Department, Abha, Saudi Arabia. \\ 2 Preparatory Institute for Literary Studies and Human Sciences of Tunis I (IPELSHT), Tunis city, Tunisia \\ ${ }^{3}$ Research Laboratory: "Biogeography, Applied Climatology and Environmental Dynamics" (BICADE), Faculty of Arts \\ and Humanities of Manouba, Tunis city, Tunisia \\ Correspondence: Allaoua Ansar, King Khalid University, Faculty of Human Sciences, Geography Department, Abha, \\ Saudi Arabia. E-mail: anserallaoua@gmail.com
}

Received: February 15, 2021

Accepted: March 15, $2021 \quad$ Online Published: April 19, 2021

doi:10.5539/esr.v10n2p1

URL: https://doi.org/10.5539/esr.v10n2p1

\begin{abstract}
Flooding is a natural phenomenon of the hydrological cycle, but it has become an urban concern in many cities around the world. Due to human intervention on the functioning of hydrosystems through infrastructure, the channelling of watercourses, the redirection of the flow and the inevitable extension of the urban landscape, floods have become a growing urban hazard. Several cities are currently facing very frequent flash floods. These floods are of various types and several factors are at the origin of their manifestation, which leaves its understanding and prevention for local stakeholders a long-term process that requires a colossal amount of work among several multidisciplinary researchers. Without denying the scientific consensus on the role of climate change, currently floods are largely caused by the senseless and irresponsible behaviour of humans. Among the cities in Saudi Arabia facing the risk of flooding is the city of Abha located in the southwest of the country, the focus of this research. It is subject to recurrent and devastating floods caused by several factors. Controversial topography, dissected orography, aggressive rainfall, accelerated and unregulated urban growth, and irresponsible human intervention are all factors that aggravate this problem. The resolution of this problem, or at least the minimization of its consequences, requires a rigorous and carefully studied approach. The appropriate knowledge by local stakeholders must be reinforced by a methodological and cartographic assessment of this phenomenon in order to mitigate its consequences. The main objective of this work is to make cartographic and methodological contributions to acquire additional knowledge on the flood hazard in the city of Abha through a statistical processing of rainfall data for the period 1978-2018, a mapping of the factors intervening on the runoff and its various behaviors and finally a synthetic analysis.
\end{abstract}

Keywords: Abha city, flood hazard, urban landscape, torrential rains, return period, runoff coefficient

\section{Introduction}

The city of Abha, located in the southwestern region of Saudi Arabia, is characterized by a morpho-structural complexity that is reflected in its topographical diversity, a "jagged" urban fabric with "peaks " and deeply incised valleys. The altitudinal differences influence the climate characteristics, originating certain names such as 'Dhabab city' or 'city of fog'. Indeed, this city is confronted with several hazards where each component of the natural environment has its share of responsibility: the substratum, the altitudes, the slopes, the climate with very variable rains, deep and steep waterways generating devastating floods, a regional framework in favor of the accentuation of all these hazards (figure 1).

The observation of the arrangement of the physical units of the city and the combination of elements of the natural environment points to a "high-risk" city. This situation is accentuated by a booming demography and a "strong and risky urbanization", the result of the scarcity of building land uses. Some neighborhoods are perched, others are located on low slopes, or on ancient terraces, indeed their proximity to waterways which are really very numerous in the Assir region. This situation results in numerous hazards that can become potential risks, including the phenomenon of submersion of built areas and streets, which can affect several places. The objective of this study is to map the areas that are prone to flooding, after highlighting the characteristics of the natural environment in terms of rainfall and hydrology. To do so, different thematic maps are used (topographic, hypsometric, slopes, hydrographic network, urban). The climatic data, particularly rainfall data (1978-2018), will be processed statistically using appropriate tools and specific parameters. 


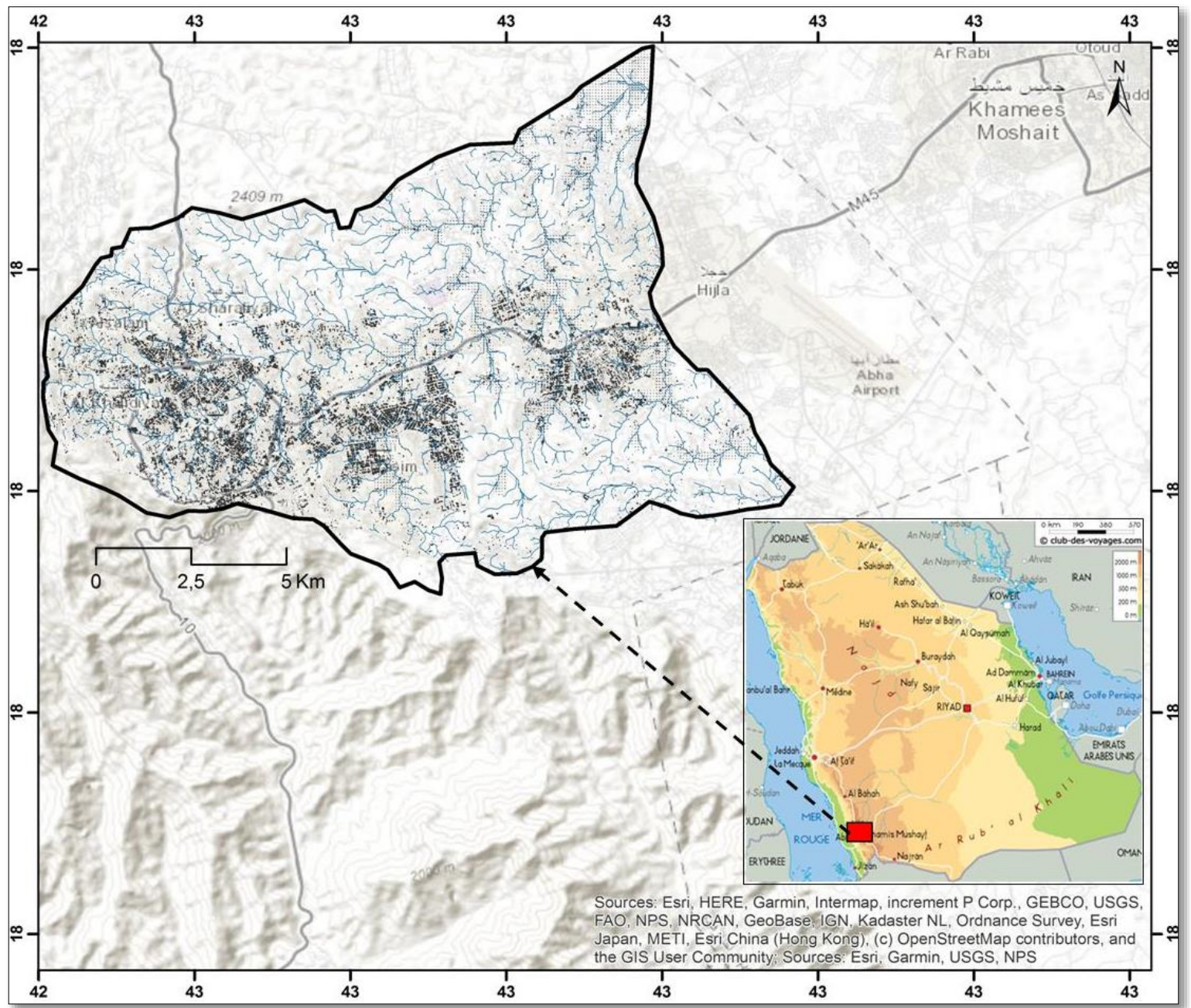

Figure 1. Location map of Abha city (source: Data base image from Arc Gis)

\section{Previous Work on Flood Study in Saudi Arabia}

Studies of food problems in the world remain Plenty, Prosperous and fortunate it is thanks to the complementarity between hydrological, climatic and geomorphological sciences. Many international action programs and scientific meetings were designed to address the various challenges associated to urban flood.

A large and sophisticated literature exists on the flooding subject in Saudi Arabia, but this one mostly concerned only Mekah, Jeddah and Ryadh frequently opposed to the phenomenon of flooding and challenges in flash flood disaster management (Shwehdi, 2006; Qari, 2009; Subyani et al., 2009;2010; 2011, Ledraa 2020; Ashammari Eissa et al, 2020; Alamri, 2011; Gomaa et al, 2011, Al-Ghamidi et 2012; Al Saud, 2015, Faddaz et al, 2016; Ameur, 2016; Abdelkarim 2019; Abdelkarim et al, 2019; Ashammari Eissa Zaidan et al, 2020, Ledraa et al, 2020). The studies of flood in urban area in Assir region remain rare and descriptive rather than quantitative. Although a considerable number of research studies have been conducted on the issue, no study has explored the Geo-morphological specifics and the various aspects of flood and its impact in Abha city, especially after urban sprawl on both sides of the Abha valley and its tributaries. This study, based on a hydroclimatic modeling approach, can provide essential additional information on the physical processes of floods, taking into account the land use and the return period of the torrential rains which affect the hydrological response of the sub-catchments and able to generate several floods.

\section{Research Method}

A separate data sets was used for this study, which deals with floods in an urban environment in order to try and understand the relationships that exist between several parameters that condition the phenomenon of flooding. In fact, floods are the 
result of the combination of at least two parameters, namely climate and hydrology, that is why we chose the hydroclimatic approach which requires the study of these two factors to more easily. To explain this problem, it was necessary to follow a multidisciplinary methodology which is based on the complementarity of statistical, graphic and cartographic analyzes and we take into account of three aspects:

\subsection{Statistical, Rational and Empirical Methods}

The first statistical method relating to the processing and analysis of climatic data with a focus on rainfall without neglecting other climatic parameters. This behavior is explained by the "direct" relationship between the rainfall variables and more precisely torrential rains and floods. A difference between PTP and PTR was made through a statistical treatment of monthly rainfall amounts. These help us to measure the relative risk of flooding on three-time scales which are year, season and month. For the 1978-2018 study period. The second is interested in the prediction of hydrological parameters and the cartographic modeling of the results.

\subsection{The Cartographic Approach}

It uses a multi-criteria database, based on the use of many documents such as: topographic map at 1/50000, geological map at 1/250000, satellite Images and Google Earth Pro Images with a high resolution and exported in UTM projection by Map Puzzle program, climatic map and exploitation of SRTM satellite image data related to the Assir region.

\subsection{The Quantitative Component}

This hydro-climatic analysis shows the sensitivity of these environments favored by a morpho-structural complexity, a topographical diversity, a "jagged" urban fabric, an accelerated and disorderly urbanization ... hence an environment very vulnerable to flooding.

\section{Climatic Aspects: Statistical Processing of Rainfall Data}

The climatic characteristics of the city of Abha are summarised with a focus on rainfall analysis, which strongly influences floods. The climate of the region of Abha is mostly a mountain climate. It is characterized by temperatures averaging around $20^{\circ} \mathrm{C}$ (Al-Quahtani. et al., 2019). The peaks range from $21.8^{\circ} \mathrm{C}$ to $31.5^{\circ} \mathrm{C}$ while the lows are between $2.3^{\circ} \mathrm{C}$ and $12.9^{\circ} \mathrm{C}$. Relative humidity is highly variable. Evapotranspiration is about $2381.0 \mathrm{~mm}$ at the annual scale. The rainfall amounts for the period 1970-1988 are about $460 \mathrm{~mm}$ (Blehed, 1986 and AL-Jerash, 1992). What about the rainfall patterns for the period 1978-2018? To answer this question this parameter will be studied through three patterns, namely annual, seasonal and monthly.

The annual rate: the average rainfall, calculated over 41 years (1978-2018) is $229.3 \mathrm{~mm}$ (The General authority of Meteorology and Environment protection). The annual rainfall amounts vary between $639.5 \mathrm{~mm}$ and $84.8 \mathrm{~mm}$. The maximum value is recorded in 1983 while the minimum is recorded in 2009.

The graphical translation of the annual rainfall quantities reveals the existence of five peaks in addition to the maximum value; the first one, in 1997, is significant, at $582.1 \mathrm{~mm}$, because they are accompanied by flood events, while the other four are less significant: $463.3 \mathrm{~mm}$ in 1990, $386.6 \mathrm{~mm}$ in 2016, 372. $3 \mathrm{~mm}$ in 1992 and $263.8 \mathrm{~mm}$ in 2013. Three minimum values are below $100 \mathrm{~mm}: 87.4 \mathrm{~mm}$ in 1994, $90.8 \mathrm{~mm}$ in 2003 and $96.8 \mathrm{~mm}$ in 2008. The trend line, inclined from left to right, suggests a decline in rainfall. A comparison between the average precipitation before and after 1999 allowed us to achieve the following results and a series of indicators:

-23 out of 41 values, that is $56 \%$ of the annual rainfall quantities, are lower than the average for the study period. The majority of these values mark the second part of the study period. The maximum values are recorded during the first part of the study period. The year 1999 is a date that separates the two parts. In other words, the rainfall decline began in 1999 when the annual total is only $180.6 \mathrm{~mm}$ (Figure $2 \mathrm{a}$ ). 


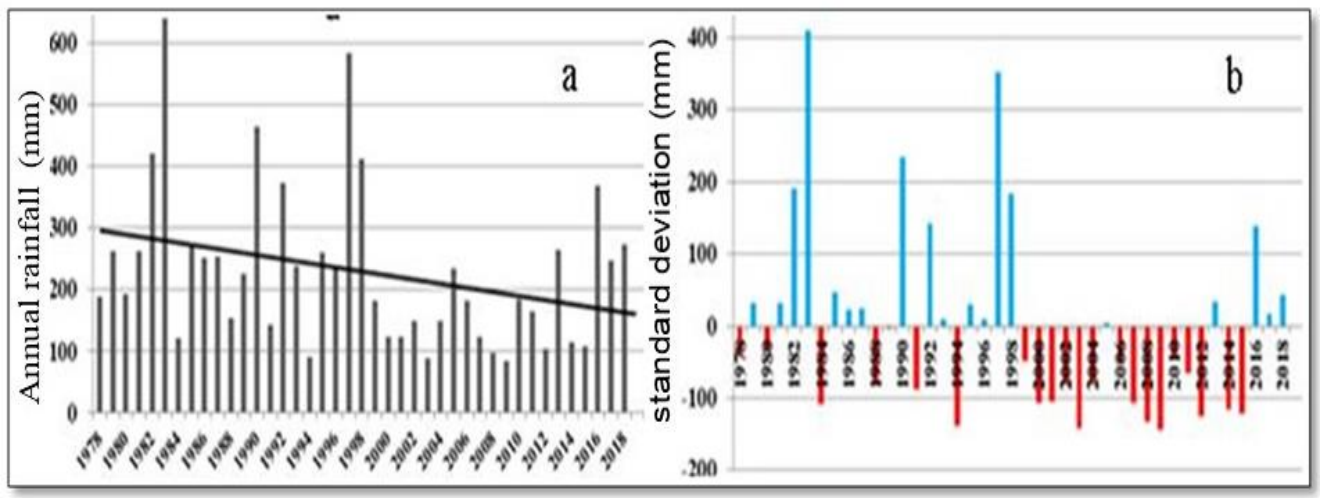

Figure 2. Annual rainfall amounts and differences 1978-2018

(Source: data processing 1978-2018)

The average rainfall for the sub-period (1978-1998), that is 21 years, is equal to $549.6 \mathrm{~mm}$. That of the second one (19992018), or 20 years, is only $319.8 \mathrm{~mm}$; this means a decline rate of $41.8 \%$, which is an alarming observation. However, the calculation of the deviations from the average annual rainfall shows the importance of the "positive" deviations. A half dozen or more large quantities were noted: $420.3 \mathrm{~mm}$ in 1982, $639.5 \mathrm{~mm}$ in 1983, $463.3 \mathrm{~mm}$ in 1990, $372.3 \mathrm{~mm}$ in 1992, $582.1 \mathrm{~mm}$ in 1997, $412.3 \mathrm{~mm}$ in 1998 and $368.3 \mathrm{~mm}$ in 2016. A few years can be distinguished by their temporal ranges, 1982-1983 and 1997-1998 (Figure 2 b).

These quantities can generate torrential rains capable of causing floods. The Coefficient of Interannual Variability calculated for the period 1978-2018 is $56.6 \%$ (Coefficient of Variation $=($ Standard Deviation / Mean) $* 100$, Jing Chen et al, 2014), a value that shows the annual rainfall fluctuations in this period. This leads to refine this situation by trying to identify, through the calculation of the standard deviation, the different degrees of rainfall.

The statistical processing allowed to identify five categories (Ansar, 2007). The $3 / 4$ of the years of the study period, that is 31 years, are marked by an average degree of rainfall, which is identified by the average related to the study period \pm one standard deviation (a). The rainfall represented by three degrees marks seven years, $16.9 \%$, of which $12.1 \%$ for the relatively rainy and $2.4 \%$ for each of the other two degrees, namely the rainy and the heavily rainy. It can be identified, respectively, by the average $+1 a+2 a$ and $+3 a$. Non-rainfall is manifested in only one degree, the relatively non-rainy with $7.3 \%$. It can be identified by the standard deviation from the mean: $(\mathrm{s})=(\mathrm{X}-1 \mathrm{a})$ and marks three years (Figure 3 ).

Seasonal rate: the seasonal indicator (Peguy, Ch. 1970) at Abha station for the period 1978-2018 is of PEHA type. Spring rains are by far the most important and constitute half of the annual total $51 \%$. Summer and winter rains come in second place with $21.5 \%$ and $21.1 \%$ respectively (Figure 3 ).

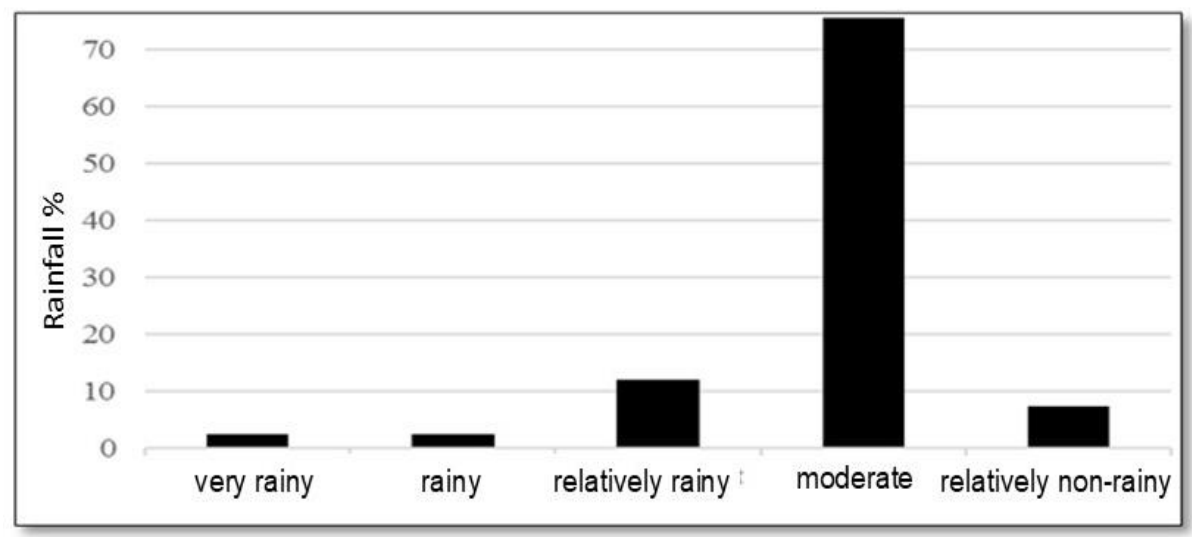

Figure 3. Annual rainfall levels in Abha station (Source: data processing 1978-2018)

Autumn rains make up only $6.3 \%$ of the annual total. Seasonal rainfall characteristics differ from season to season; average values, obtained from Total values, range from $14.4 \mathrm{~mm}$ in autumn to $116.9 \mathrm{~mm}$ in spring. In summer and winter the seasonal averages are $51.6 \mathrm{~mm}$ and $46.3 \mathrm{~mm}$ respectively. Maximum values exceed $400 \mathrm{~mm}(437.7 \mathrm{~mm}) \mathrm{in}$ spring, 300 $\mathrm{mm}(370.9 \mathrm{~mm})$ in winter. They are above $100 \mathrm{~mm}(125.8 \mathrm{~mm})$ in summer and below this value $(83.1 \mathrm{~mm})$ in autumn. The minimum values are very low. They are practically zero in autumn and winter and are only $20.6 \mathrm{~mm}$ in spring and 
$9.9 \mathrm{~mm}$ in summer.

In spring: The spring is considered the wettest season in Abha city. It receives on average, for the period 1978-2018, $116.9 \mathrm{~mm}$, obtained from Total values. The seasonal rainfall quantities recorded are relatively variable. The maximum value is $437.7 \mathrm{~mm}$ while the lowest is only $20.6 \mathrm{~mm}$. The ratio between the two extremes is 21 . This indicates the variable nature of these spring rains. They can exceed the $400 \mathrm{~mm}$ threshold, as in 1997 with $437.7 \mathrm{~mm}$. Six seasonal values are above $200 \mathrm{~mm}(1998,1990,2016,1983,1981$ and 1986), twelve are above $100 \mathrm{~mm}(2013,1989,1985,2018,1987,1995$, 2006, 1982, 2004, 1993, 1980 and 1996), fourteen below $100 \mathrm{~mm}$ and nine below $50 \mathrm{~mm}(2001,2008,2017,1988,2015$, 2003, 2009, 2011 and 1992).

The maximum values are recorded before 1999 while the minimum values are recorded after 1999. This is explained by the trend line of spring rainfall amounts, which tend to decrease (Figure 4 a). The graphical representation of the variations from the average rainfall relative to the spring season shows that some years positively stand out in a strong way: 1981, 1986, 1990, 1997, 1998, and 2016. They recorded respectively $108.8 \mathrm{~mm}, 92 \mathrm{~mm}, 171.5 \mathrm{~mm}, 320.8 \mathrm{~mm}, 178.7 \mathrm{~mm}$ and $148.1 \mathrm{~mm}$ (Figure $4 \mathrm{~b}$ ). These relatively high quantities can cause flooding.

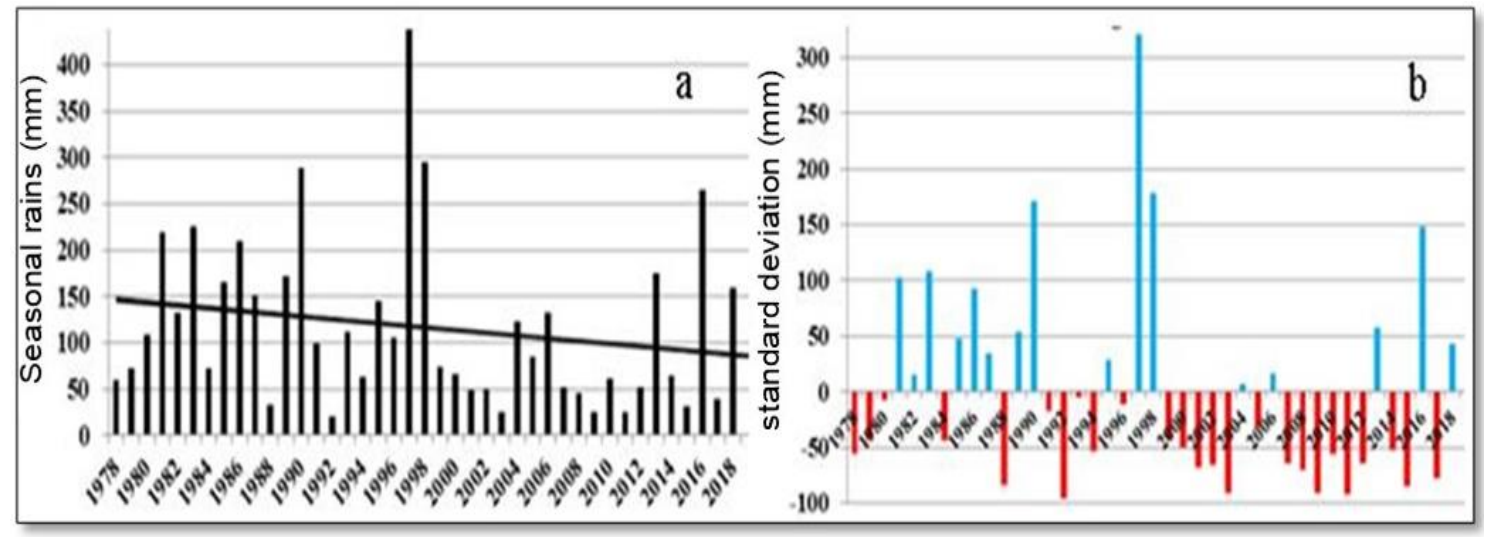

Figure 4. Spring rainfall quantity and variations 1978-2018

(Source: data processing 1978-2018)

In summer: In the summer, the seasonal average rainfall becomes $51.6 \mathrm{~mm}$. It is less wet than in spring. Seasonal values range from $125.8 \mathrm{~mm}$ to $9.9 \mathrm{~mm}$. However, with the exception of four values recorded in 1992, 2010, 1978 and 1997, which exceed $100 \mathrm{~mm}$, the rest is below this threshold. Some values stand out constituting a four-year cycle: $91.6 \mathrm{~mm}$ in $1995,81.5 \mathrm{~mm}$ in $1996,100.9 \mathrm{~mm}$ in 1997 and $91.6 \mathrm{~mm}$ in 1998 in addition to a few other isolated years such as 1978 with $103.3 \mathrm{~mm}, 1992$ with $125.8 \mathrm{~mm}$ and 2010 with $105.9 \mathrm{~mm}$. Some years are characterized by low seasonal summer totals as in 1980, 1985, 1986, 2004, 1989, 1991, 1994 and 2008 which are below $20 \mathrm{~mm}$. This observation indicates a variable character, such a coefficient of variation equal to $60.8 \%$. It is illustrated by an almost horizontal trend line (Figure 5a). The graphic representation of the deviations from the average shows a certain homogeneity between the two aspects of the rainfall evolution. They are characterized by their weakness, although some fairly large values, such as $74.2 \mathrm{~mm}$ in 1992, attract attention (Figure 5b). The weakness of these positive deviations is a sign of a low probability of flooding.

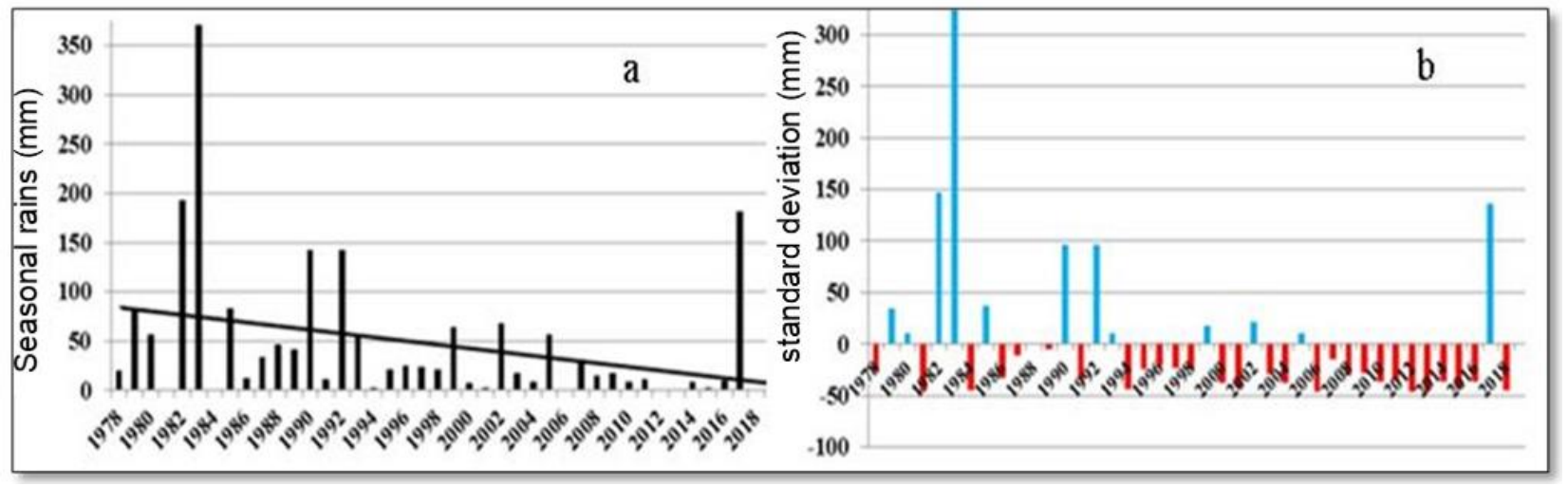

Figure 5. Summer rainfall quantities and variations 1978-2018 
In Winter: The statistical processing of this season's data highlights certain characteristics. The average seasonal rainfall for this season, compared to that of spring, is very low. It is only $46.3 \mathrm{~mm}$. In addition, the winter rainfall quantities are very variable as shown by the coefficient of variation equal to $153.5 \%$. The recorded rainfall quantities can exceptionally reach relatively high values; $370.9 \mathrm{~mm}$ in 1983. However, they are nil (0 mm in 1981, 2006, 2012 and 2013) or almost nil (less than $10 \mathrm{~mm}$ in ten years) during the years 2016, 2010, 2014, 2004, 2000, 2001, 2015, 1994 and 2018. With the exception of a few cases, it can be noted that the highest quantities are recorded before 1999, while the low quantities are recorded after this year. This finding, which indicates a decline in rainfall, is confirmed by a trend line tilted from left to right, which suggests values predicting flooding and harbinger of flood hazard. (Figure 6a).
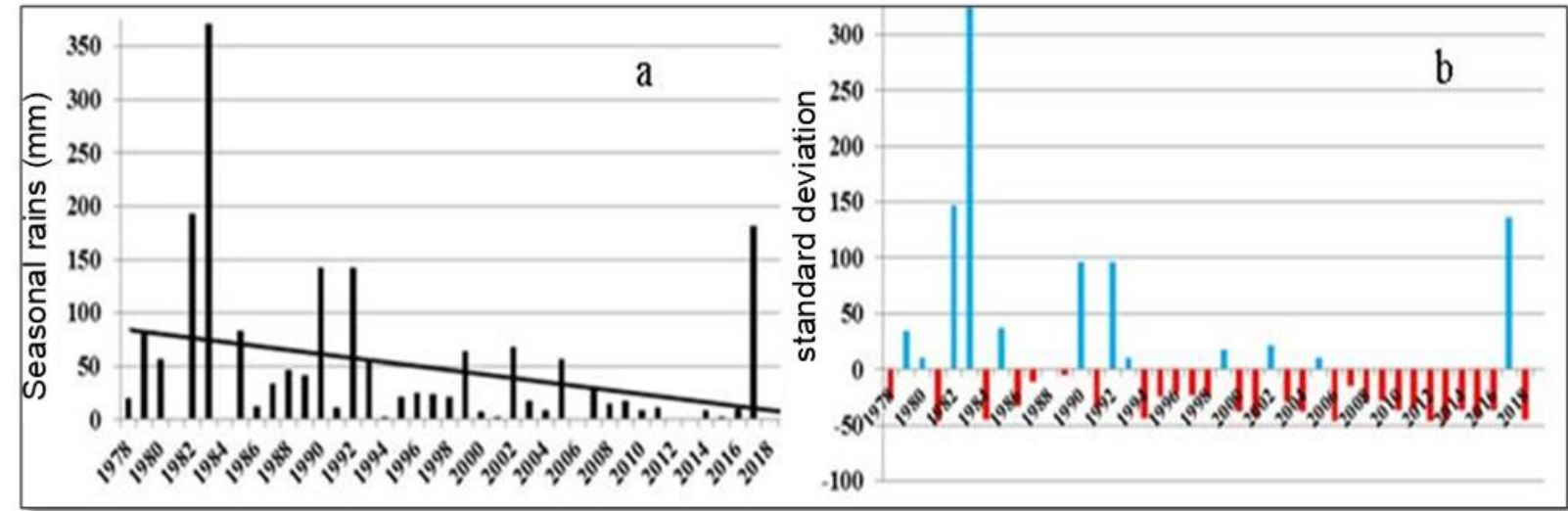

Figure 6. Winter rainfall amounts and variations 1978-2018

(Source: data processing 1978-2018)

The result of the calculation of the deviations from the average shows two remarkable facts: the first relates to the low negative deviations, while the second relates to certain positive deviations that are remarkably distinguishable. Significant seasonal totals of $193 \mathrm{~mm}, 370.9 \mathrm{~mm}, 143 \mathrm{~mm}, 142.8 \mathrm{~mm}$ and $182 \mathrm{~mm}$ are recorded for the years 1982, 1983, 1990, 1992 and 2017 respectively (Fig. 6 b). These values are precursors to flooding.

In autumn: The seasonal rainfall amounts never exceed $100 \mathrm{~mm}$ or even $50 \mathrm{~mm}$ in autumn, with the exception provided for the years 1992 and 2011 which record, respectively, $83.1 \mathrm{~mm}$ and $50 \mathrm{~mm}$. For the rest of the winter seasons in the period 1978-2018, rainfall is below $50 \mathrm{~mm}$. Some values are nil (1989 and 2017), and eighteen are below $10 \mathrm{~mm}$. This shows the scarcity in winter season totals. However, in spite of this observation, it can be noted that these winter rains are clearly increasing. Indeed, the trend line is slightly inclined from right to left (Figure 7 a). The graphical representation of the deviations from the average shows only few anomalies. However, there is one fact related to the end of the study period that must be noted, namely the importance of the positive variations which indicate flooding (Figure $7 \mathrm{~b}$ ).
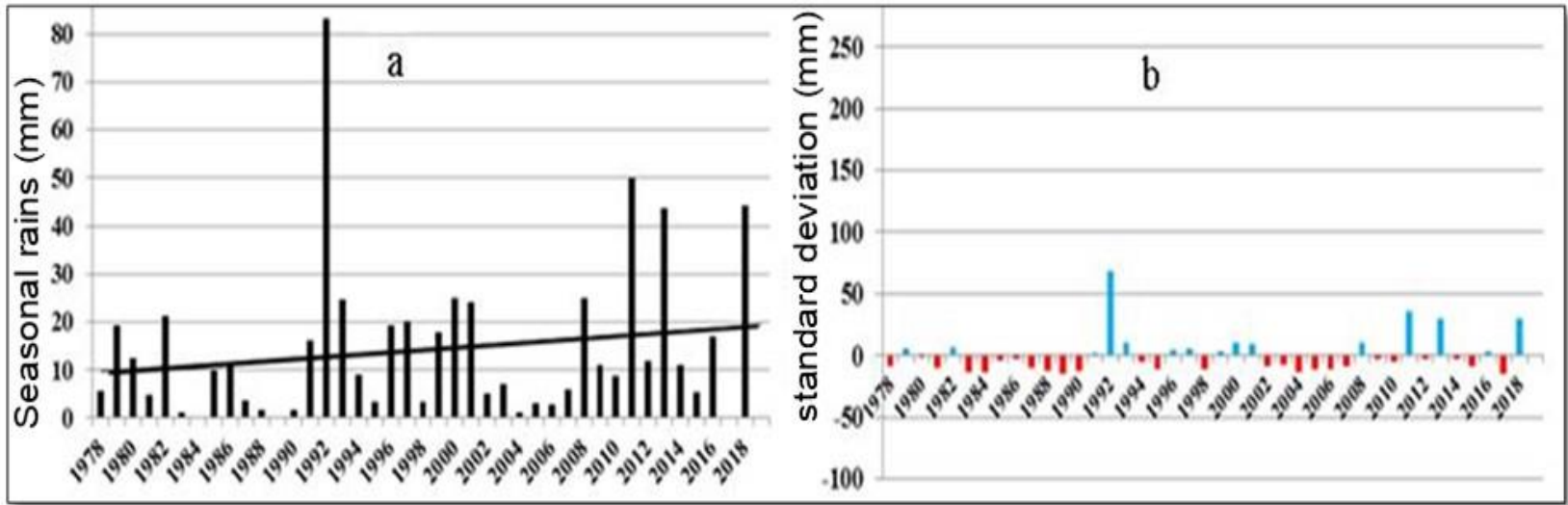

Figure 7. Fall rainfall amounts and variations 1978-2018

(Source: data processing 1978-2018)

The trend lines for each season indicate a decline in spring and winter rainfall, an increase in fall rainfall and stability in summer rainfall. The annual rainfall trend is declining. Positive variations, which are indicators of torrential rains leading to a risk of flooding, characterize the years 1982, 1983, 1990, 1992, 1997, 1998 and 2016. Seasonally, the risk of flooding is very frequent in spring, frequent in summer and less frequent in winter except for the beginning of the study period and 
in autumn (Blehed, 1986).

Monthly rate: The monthly rainfall amounts start at a low level of $15.5 \mathrm{~mm}$ in January. They progress to reach a peak in April with $50.9 \mathrm{~mm}$. They quickly decline in June with only $8.3 \mathrm{~mm}$. In July and August, they rose sharply to $19.9 \mathrm{~mm}$ and $23.8 \mathrm{~mm}$ respectively. From September to December, the rainfall totals are the lowest. They are less than $6 \mathrm{~mm}$ (Figure 8).

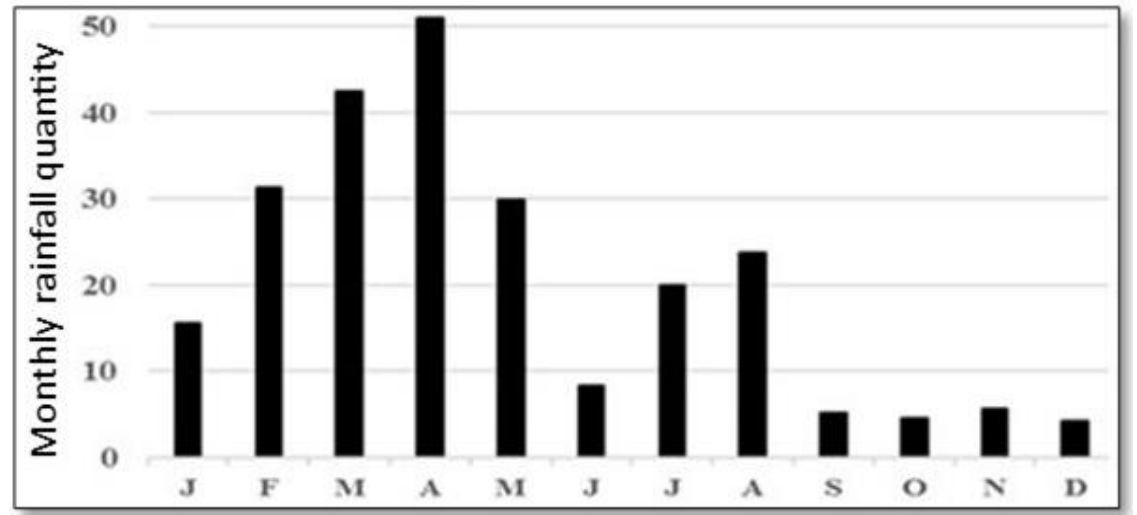

Figure 8. Monthly rhythm of precipitation 1978-2018

(Source: data processing 1978-2018)

In the study of the monthly rate during the period 1978-2018, that is 492 months, it is sufficient to focus on the temporal fluctuations through statistical processing by calculating the deviations from the average and their graphical representation, which also allows to identify the characteristics relative to the temporal distribution of monthly rainfall amounts. Emphasis will be placed on positive deviations that indicate potential flooding. Some of the positive deviations are quite noticeable. Only values greater than $30 \mathrm{~mm}$, representing potentially torrential rainfall, will be recorded. To identify torrential rains, two steps were carried out:

1- First of all, an identification has been done on a monthly basis, the rainfall amounts higher than $30 \mathrm{~mm}$. This is what will be called potentially torrential rain or potential torrential rain (PTR). To do so, positive deviations from the average for all months in the study period are processed. The result of this step gives us 45 PTRs. In other words, 45 months are marked by this phenomenon, or $9.1 \%$. The PTRs make up $1 / 10$ of the total.

2- Secondly, the truthfulness of these PTRs is verified by consulting the daily data. This step, carried out in a tedious way, has reduced the number of real torrential rains (RTRs) to only 13 or $0.08 \%$. This confirms the exceptional nature of the phenomenon of flooding.

For the first stage, carried out at the monthly level, that is a total of 492 months in the period 1978-2018, the results are as follows:

*In January, five showers are counted: $65.1 \mathrm{~mm}$ in 1992, $55.6 \mathrm{~mm}$ in 1979, $41.9 \mathrm{~mm}$ in 1985, $40.7 \mathrm{~mm}$ in 2005 and 38.5 $\mathrm{mm}$ in 1999. They took place between 1985 and 2005.

*The month of February, just like the previous one, counts five showers. However, these are more important: $333.9 \mathrm{~mm}$ in $1983,153.9 \mathrm{~mm}$ in $2017,124.1 \mathrm{~mm}$ in 1982, $106.6 \mathrm{~mm}$ in 1990 and $32.6 \mathrm{~mm}$ in 1992. Except for 2017, rains above 30 mm were recorded before 1992 .

*In March, seven potentially torrential rains are counted: $374.5 \mathrm{~mm}$ in 1997, $142 \mathrm{~mm}$ in 1998, $93.2 \mathrm{~mm}$ in 1981, 66.8 $\mathrm{mm}$ in 1986, $60.2 \mathrm{~mm}$ in $1983,45.2 \mathrm{~mm}$ in 1995 and $41.1 \mathrm{~mm}$ in 1989. It should be noted that there is a cycle of two successive years, 1997 and 1998.

*In April, the number of potentially torrential rains is nine. They record $195.6 \mathrm{~mm}$ in 2016, $179.1 \mathrm{~mm}$ in 1990, $66.8 \mathrm{~mm}$ in 2004, $56.7 \mathrm{~mm}$ in 2018, $54 \mathrm{~mm}$ in 2006, $53.2 \mathrm{~mm}$ in 1986, $46.2 \mathrm{~mm}$ in 1982, $46.1 \mathrm{~mm}$ in 1983 (two successive years) and $43 \mathrm{~mm}$ in 1993.

*In May, the number of showers is only five and take place in 2013 with $83.7 \mathrm{~mm}, 51.5 \mathrm{~mm}$ in 1985, 47.6 $\mathrm{mm}$ in 1998 , $43.5 \mathrm{~mm}$ in 1981 and $37.1 \mathrm{~mm}$ in 1984. These rains occurred at the beginning of the study period.

*In June, a single shower (50.4 mm), considered potentially torrential, was recorded in 1996.

*The month of July recorded four potentially torrential rains. $69.8 \mathrm{~mm}$ in 1978, $57 \mathrm{~mm}$ in 2010, $35 \mathrm{~mm}$ in 1988 and 32.1 $\mathrm{mm}$ in 1995. 
*As in July, August has four potentially torrential showers. They took place in 1992 with $90.1 \mathrm{~mm}, 37.9 \mathrm{~mm}$ in 2005 , $37.8 \mathrm{~mm}$ in 1987 and $35.3 \mathrm{~mm}$ in 1997.

*Only two showers are recorded in September: $39.4 \mathrm{~mm}$ in 2011 and $34.6 \mathrm{~mm}$ in 1992.

*In October, only one rainfall is recorded in 2018 with $39.8 \mathrm{~mm}$.

* In November, two showers were recorded in November with $38.1 \mathrm{~mm}$ in 2013 and $36.7 \mathrm{~mm}$ in 1992.

*In December, no potentially torrential rain was recorded in this month (Figure 8).

The number of potentially torrential rainfall is 45 . The month of April, at $20 \%$, is characterized by the importance of these rains. For the period 1978-2018, one day out of five is potentially torrential. March and May, spring months, account for half of these rains. January and February (winter months) and June and August (summer months) share 4/5 of the rest (Figure 9). For the second stage, it was decided to process the daily data for the period 1978-2018, that is to say 14965 values. Six years are concerned by this phenomenon; two years (1992 and 1996) before 1999 and four years (2013, 2014, 2016 and 2017) after it. At the monthly level, torrential rains occur in February 46.1\%, March and May 15.3\% each and April, June and August with 7.6\% each. Rainfall amounts related to torrential rains range from $37 \mathrm{~mm}$ to $279.9 \mathrm{~mm}$ (The General authority of Meteorology and Environment protection) (Table 1).

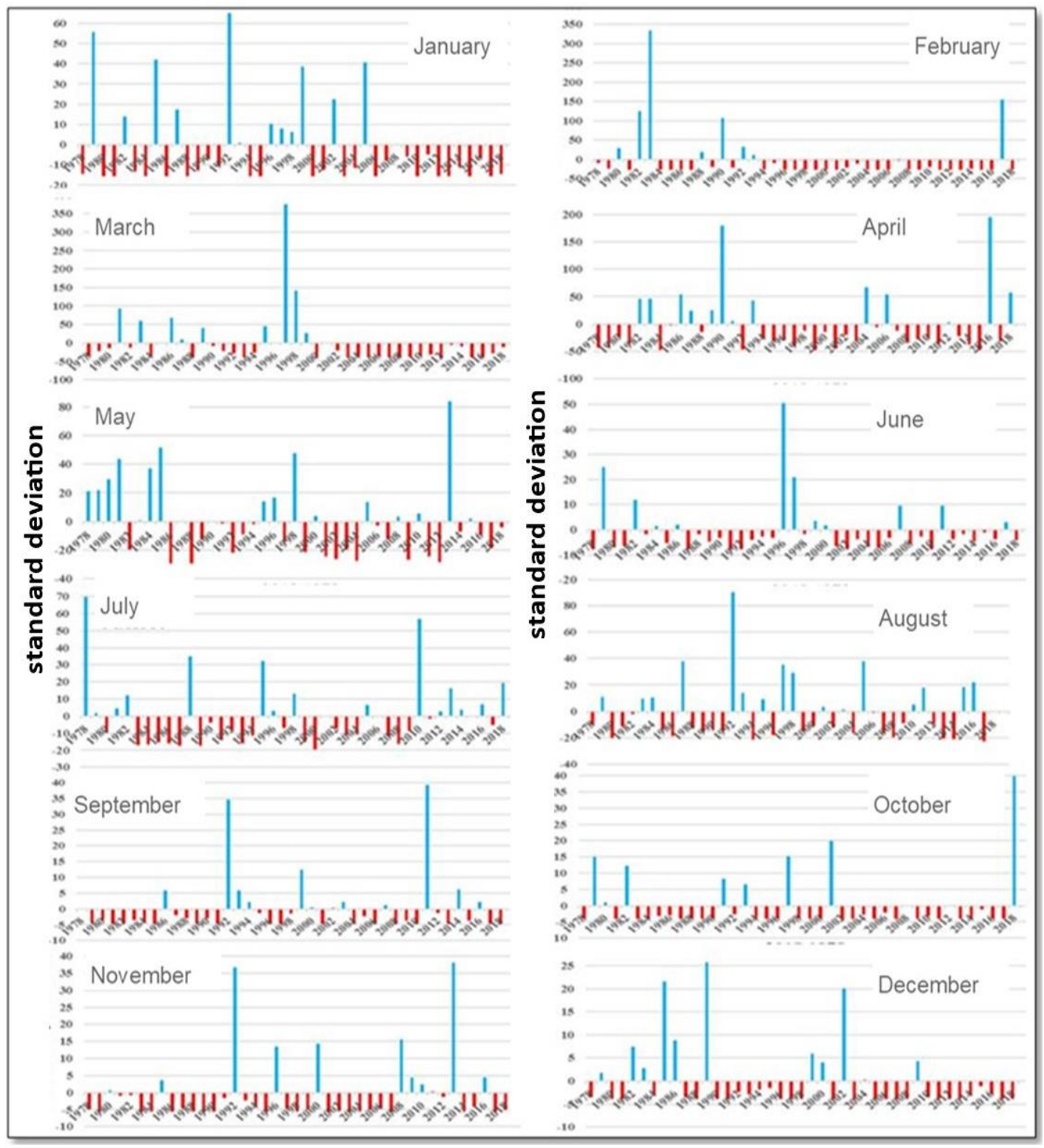

Figure 9. Deviations from the average monthly precipitation (1978-2018)

(Source: data processing 1978-2018) 
These exceptional daily rains affect the hydrological response of the sub-catchments and can generate floods given the recurrence of extreme rainfall events reinforced by the presence of a high relief(Blehed, 1986 ; Jade, 1987; Prakash, 2004 et Abdelkarim, 2019). The following approach consists in jointly analyzing the hydrological response of the different subcatchments according to the urban expansion that has marked the city of Abha over the last few decades (Figure 10).

Table 1. Torrential rains (Source: data processing 1978-2018)

\begin{tabular}{|c|c|c|c|}
\hline Years & Months & Day's date & Quantity (mm) \\
\hline 1992 & February & 1 & 99.0 \\
\hline$/ /$ & February & 4 & 45.9 \\
\hline 1996 & June & 15 & 279.9 \\
\hline 2013 & Mars & 24 & 46.9 \\
\hline$/ /$ & May & 1 & 44.9 \\
\hline$/ /$ & May & 19 & 43.9 \\
\hline 2014 & Mars & 30 & 55.0 \\
\hline 2016 & April & 14 & 175.0 \\
\hline$/ /$ & August & 1 & 37.0 \\
\hline 2017 & February & 14 & 59.9 \\
\hline$/ /$ & February & 17 & 44.9 \\
\hline$/ /$ & February & 18 & 59.9 \\
\hline$/ /$ & February & & 68.0 \\
\hline
\end{tabular}

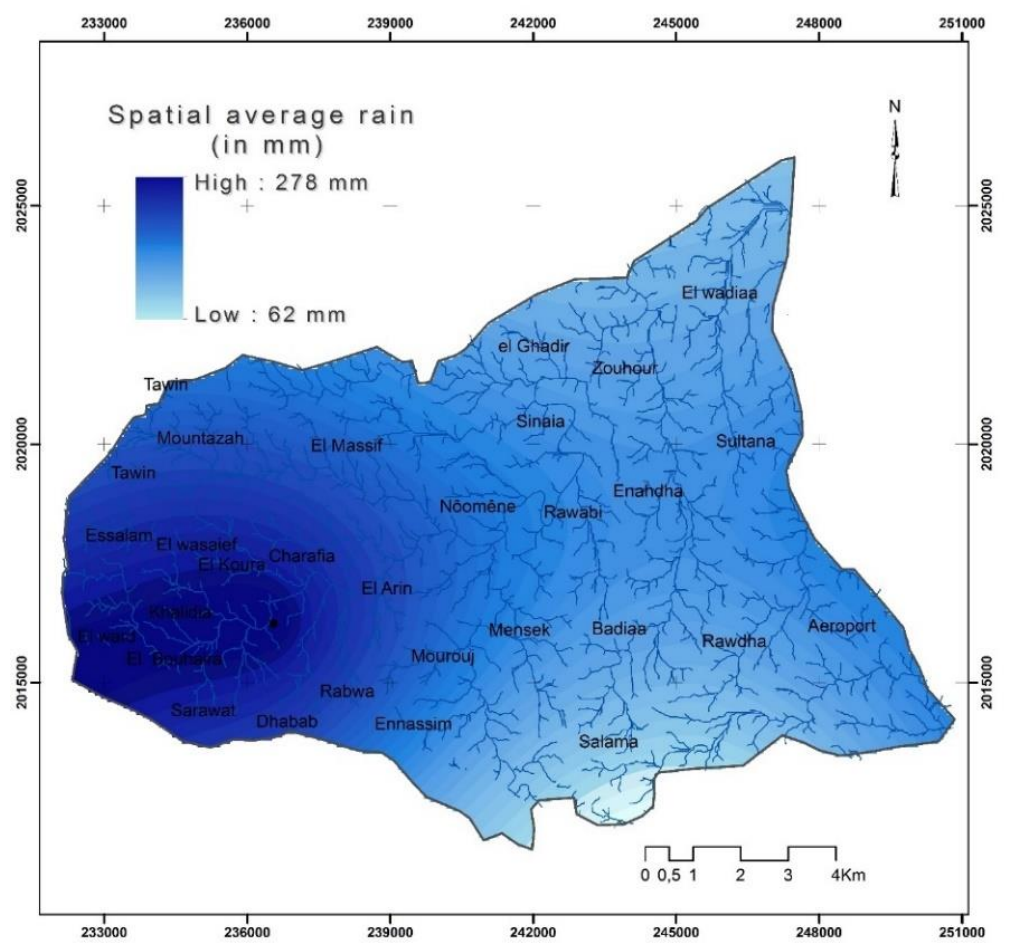

Figure 10. The spatial average rains in the city of Abha between $1978-2018$

(Source: Data from the General Authority for Meteorology and environmental Protection 1978 -2018) 


\section{An Inventory of the Current Urban Extension}

The land use map (figure 11) shows a large urban extension in the southwestern sector in the first place and in the eastern part in the second place. Residential development has occurred around Wadi Abha and its tributaries, which was considered in the past as a source of water for the sustainability of the agricultural sector. With the acceleration of urbanization, the majority of the streams are now conducted in artificial concrete pipes.

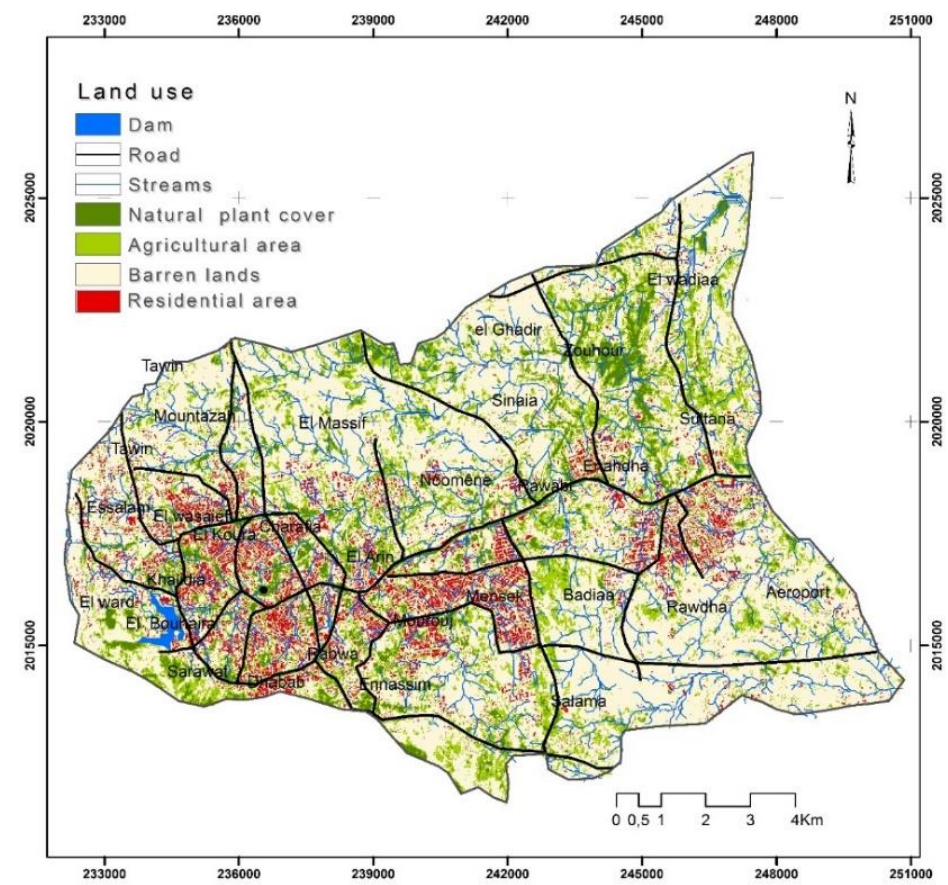

Figure 11. Land use map of Abha city (Source: work carried out based on the Google Earth Pro Image, 2019 and field observation)

\subsection{An urban sprawl in vulnerable sectors}

One of the first basics in the management of urban development is to have sufficient knowledge of the risk in order to be able to provide local stakeholders with a solid database capable of increasing the resistance of the city to the risk of flooding. Indeed, urban sprawl alone does not generate risk. But once it has developed in low-lying areas, the residential pattern will further increase the runoff coefficient, especially with more extreme, widespread and long-lasting climate change (Helga, 2014). The city of Abha, with its highly undulating topography and variable and intense rainfall, is a real example of a city threatened by flash floods that do not leave enough time to react and take appropriate measures. The urban fabric increased dramatically by $200 \%$ between 2002 and 2020, mainly to the east and northeast of the old centre. (Google Earth Pro image 2002 and 2020). This growing city is constantly increasing the number of real estate projects in flood-prone areas (such as the Dourat el Mensek districts, El Mensek and currently the El Badia districts) (Figures 12 and 13) (Qahtani, 2019).
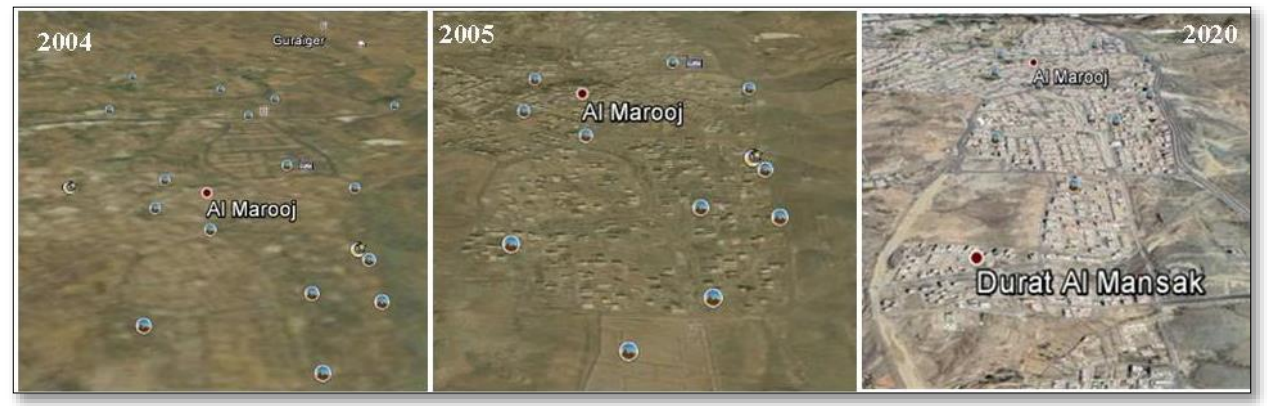

Figure 12. The rapid expansion of the El Mensek - El Mourouj district in the middle of the floodable section of Wadi Charaf (tributary of Wadi Abha) (Source: Google Earth Pro Image, 2019) 


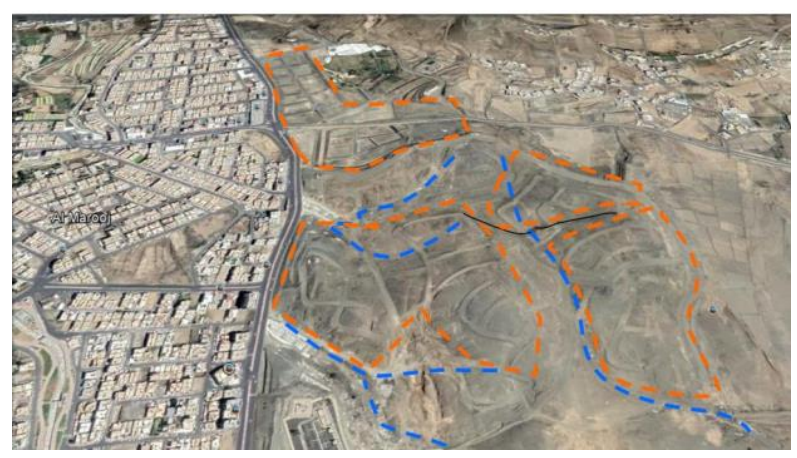

Figure 13. Programming of new neighborhoods in high-risk sectors in the el Badiaa neighborhood (Source: Google Earth Pro Image, 2019)

All of them are developed on slightly undulating land in saddles dominated by mounds of 2 to $5 \mathrm{~m}$ in height. Roads and habitats located on the middle and lower slopes cannot escape torrential floods, which are typical of small watersheds with convective rainfall. It should be noted that floods of a technical nature are not taken into consideration, such as sewer backups, counter-slopes in the drainage of rainwater, pumping system failures and dam releases (Helga, 2014). Assessing these technical risks requires a huge amount of work with local state authorities.

\subsection{A Growing Housing Density in the Flood Expansion Area}

The habitats threatened by the rise in water levels during heavy rains are located in very gently sloping areas, saddle areas or at the convergence of several streams that are likely to overflow (Figure 14). It is also important to bear in mind the transversal and longitudinal layout of the watercourses, most of which are very narrow on the one hand and forming elongated meanders on the other.

As a result, the narrowing of the valleys into narrow, winding gorges can create jammed areas blocked by cars and coarse elements being carried, leading to the formation of a water impoundment upstream. As the force of the water increases, a certain rupture of this impoundment will occur in the form of a flush, so downstream districts may be flooded abruptly. This observation concerns the two neighborhoods El Mensek and Sharafia where the risk of flooding threatens $77 \%$ to $80 \%$ of the built-up area, based on the inventory of flooded areas given by the authorities.

During the floods of February 2017, these districts along with El Morouj and some sectors of the El Mouathfine district were the first to be affected. In the five districts of Soltana, Ennassim, Rawdha, Noomène and Ezzouhour, the risk threatens between $31 \%$ and $56 \%$ of the built-up area, based on the inventory of flooded areas given by the authorities (Table 2 and Figure 14). 


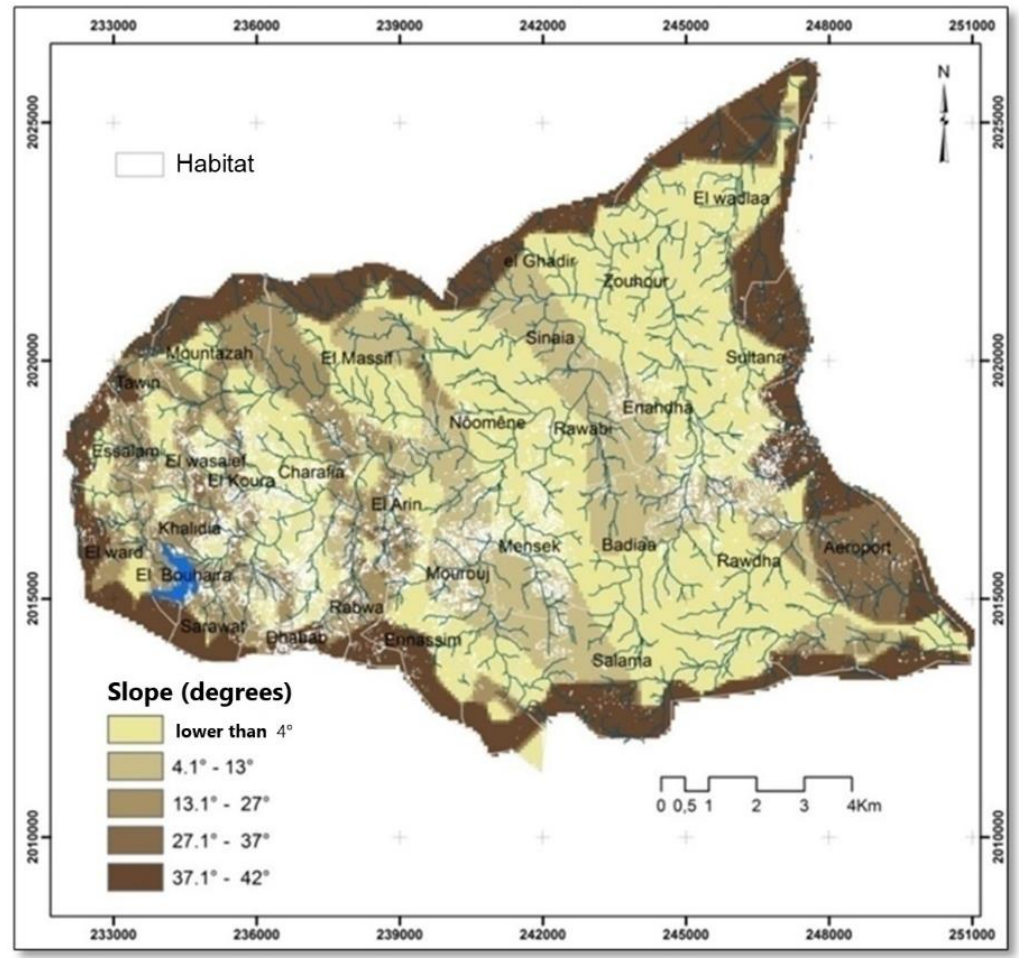

Figure 14. The slopes map of Abha city and its surrounding areas. (Source: map produced on the basis of the topographic map of Abha)

However, the magnitude of the risk is closely linked to the intensity of the rainfall, its duration, the pre-existing soil moisture and the state of the sewers. The Asserian community still remembers traumatic catastrophic rainfall events over time (Blehed, 1986). There were long periods of very few floods, which led the population to settle unconsciously in the areas where streams overflowed.

Table 2. Estimate of the area subject to flood risk

(Source: work carried out based on the Google Earth Pro Image, 2019 and field observation)

\begin{tabular}{|c|c|c|c|c|c|}
\hline District & $\begin{array}{c}\text { Total area } \\
\mathrm{Km}^{2}\end{array}$ & Built area & $\begin{array}{c}\text { Sectors } \\
\text { disposed to risk } \\
\text { at } \mathrm{km}^{2}\end{array}$ & $\begin{array}{c}\text { Risk } \\
\%\end{array}$ & Built area $\%$ \\
\hline El Mensek & 4,84 & 2,44 & 1,88 & 77,0 & 50,4 \\
\hline Ennassim & 3,28 & 1,38 & 0,599 & 43,4 & 42,1 \\
\hline Noomène & 6,9 & 1,67 & 0,537 & 32,2 & 24,2 \\
\hline el Badiaa & 5,65 & 1,2 & 0,24 & 20,0 & 21,2 \\
\hline Mourouj & 7,278 & 3,54 & 0,49 & 13,8 & 48,6 \\
\hline Rawdha & 11,58 & 5,82 & 1,81 & 31,1 & 50,3 \\
\hline Soltana & 4,87 & 2,73 & 1,531 & 56,1 & 56,1 \\
\hline Ennahdha & 3,812 & 1,51 & 0,47 & 31,1 & 39,6 \\
\hline Ezzouhour & 6,07 & 0,276 & 0,11 & 39,9 & 4,5 \\
\hline Massif & 13,17 & 1,8 & 0,14 & 7,8 & 13,7 \\
\hline Charafia & 2,61 & 1,5 & 1,2 & 80,0 & 57,5 \\
\hline Centre ville & 5,194 & 5,09 & 1,6 & 31,4 & 98,0 \\
\hline Khalidia & 1,375 & 1,21 & 0,16 & 13,2 & 88,0 \\
\hline
\end{tabular}


In order to map this threat reliably, it would be advisable to use instantaneous records of the flows of the various streams and rivers (Abdelkarim, 2019). One difficulty is how to estimate extreme flow values for the majority of ungauged streams in the study area. Recent hydrological studies have been carried out on a Jizan watershed southwest of Abha, but it would be hazardous to rely on extrapolation of these results for extreme values in a complex watershed (Abdelkarim, 2019). Thus, the estimation of floods in the various ungauged streams in the city of Abha proves difficult. What remains to be done is to develop an alternative method capable of carrying out a general mapping of residual flood risk. A difference will be made between flooded areas and flood risk areas based on morphometric, hydrological and pluviometric parameters.

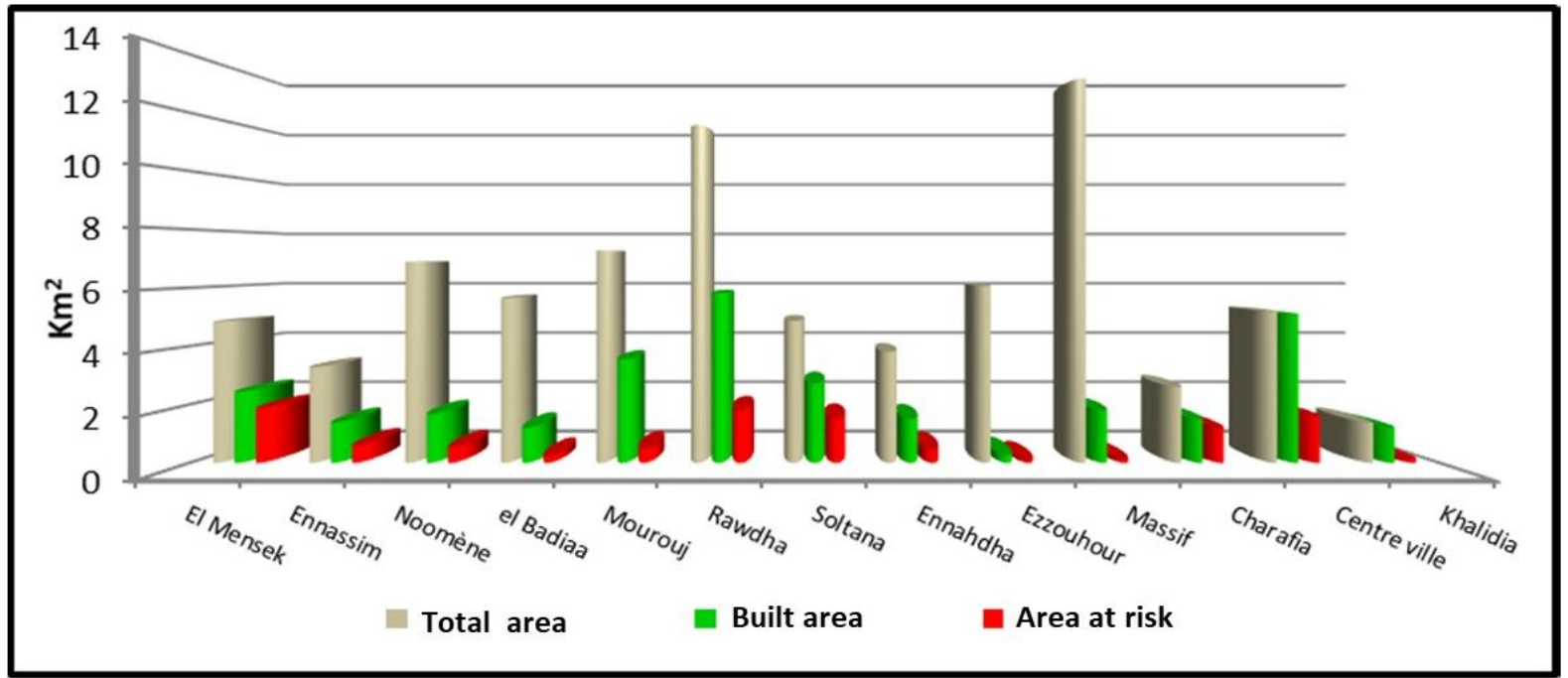

Figure 15. Comparison of the risk rate between the different districts (Source: results of processing data from the land use map, 2019)

\section{Overview of the Hydrological Response of Sub-watersheds}

The study of floods differs in its approach between rural, urban and peri-urban areas. The coefficients of runoff, soil sealing, roughness, and concentration time are parameters of great importance in urban hydrology (Prakash, 2004 et Helga, 2014). The map of flood zones will be realized by superimposing these different parameters on the extreme values of torrential rains and the density of residential areas.

\subsection{The Soil Sealing Index}

The soil sealing coefficient is a parameter that covers the built-up space on one hand and the roads, parking lots, sidewalks and terraces on the other hand (Helga, 2014). It exceeds the threshold of $98 \%$ in the downtown area and its borders. It also increases in areas with predominantly mixed residential areas in the older districts that have the highest densities and decreases in peri-urban areas with predominantly suburban housing (Prakash, 2004 et Helga, 2014). Its estimation was made through the extraction of built land, roads and parking lots based on STRM satellite image, and then calculated in relation to the total area of each district. It is well known that this parameter directly affects the peak flood flow (Table $3)$.

\subsection{The Runoff Coefficient}

It is a coefficient calculated in an empirical way on the basis of a referential that requires the elaboration of the land use map that is specific to the city of Abha (Table 3 and figure 16). It indicates the ratio between net rainfall (height of water runoff at the outlet of a catchment area) and gross rainfall (height of precipitated water) (Laborde, 2000 ; Prakash, 2004 et Giret, 2007). It is a multivariate indicator that depends, among other things, on the land use, the nature of the soil, its water status, the slope and the characteristics of the vegetation cover. It is considered constant on a spatio-temporal scale. But in reality this parameter changes a lot from one season to another and from one sector to another according to the characteristics of each study area (Laborde, 2000; Prakash, 2004 et Giret, 2007). The spatial modeling of this parameter at the scale of the city of Abha shows a perfect conjunction between the sectors with a high residential density and the highest values (0.95) where the runoff water level is much more important than the sectors with an index very close to 0 . These are bare land and agricultural land where the infiltration far outweighs the runoff (Figure 16). 
Table 3. The runoff coefficient by district (Source: Results of processing data from the Google Earth Pro Image, 2019)

\begin{tabular}{|c|c|c|c|}
\hline District & $\begin{array}{l}\text { Runoff coefficient } \\
\%\end{array}$ & District & $\begin{array}{c}\text { Runoff coefficient } \\
\text { coefficient } \%\end{array}$ \\
\hline El Mensek & 56,4 & Soltana & 59,1 \\
\hline Ennassim & 46,1 & Ennahdha & 42,6 \\
\hline Noomène & 24,2 & Ezzouhour & 7,5 \\
\hline el Badiaa & 21,2 & Massif & 16,7 \\
\hline Mourouj & 55,6 & Charafia & 61,5 \\
\hline Rawdha & 50,3 & Centre ville & 98,0 \\
\hline Soltana & 59,1 & Khalidia & 90,8 \\
\hline
\end{tabular}

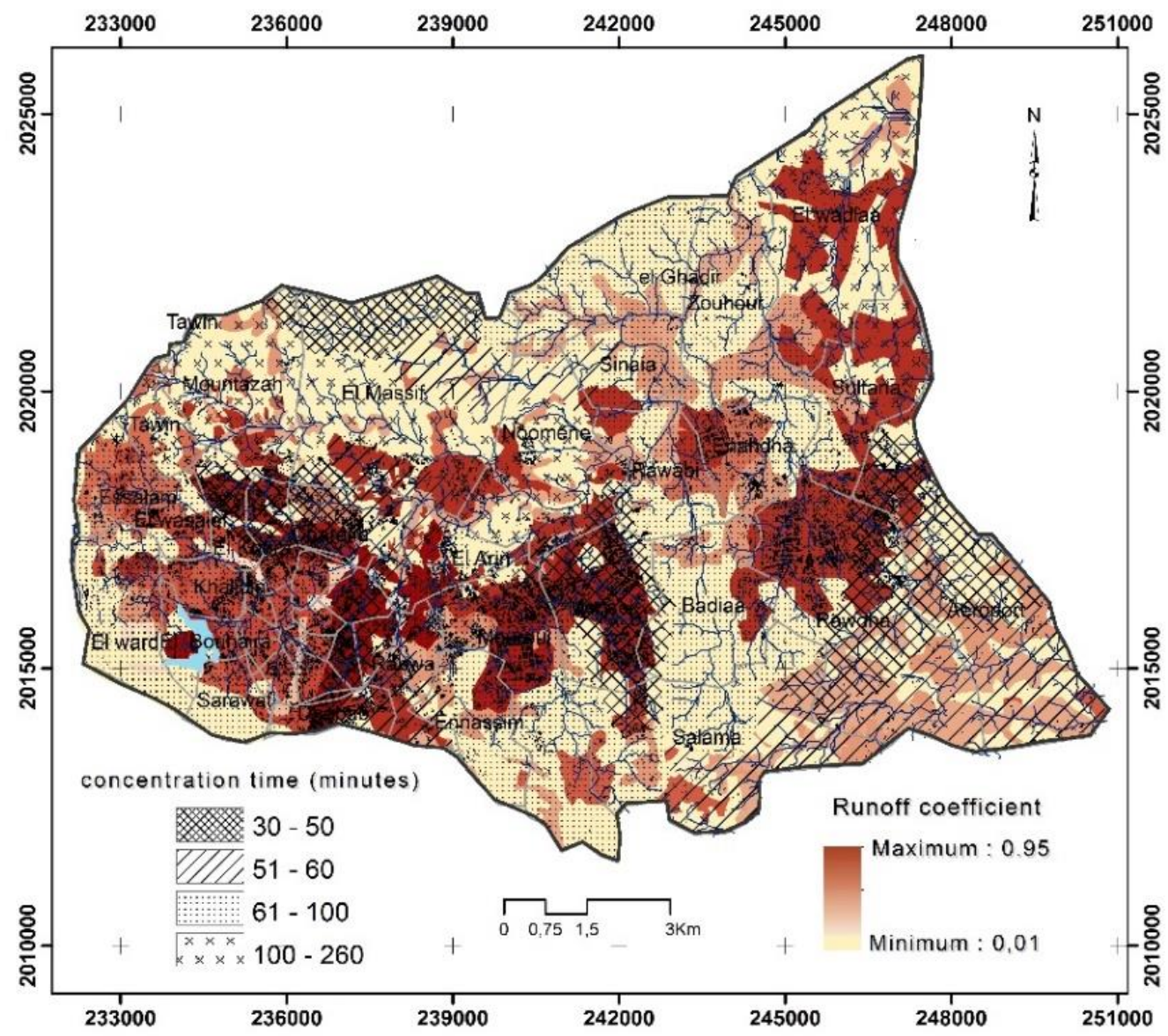

Figure 16. Runoff coefficient map in the city of Abha (Source: results of processing data from the land use map, 2019)

\subsection{Concentration Time}

Concentration time refers to the length of time it takes for a raindrop to reach the outlet. It is closely related to the topography, land use patterns and morphometric conditions of sub-watersheds (El Qhatani, 2019). It is calculated through several empirical methods based on hypsometric and morphometric criteria at different scales.

It has been chosen to estimate the concentration time through 4 formulas: Giondotti, Passini, Ventura and Turrazza (Giandotti,1934 et 1940; Kirpich, 1940; Prakash, 2004 ; Abhas et al., 2012; Almeidai et al., 2014; Azaiez, 2016; Quefféléan and Unanoa, 2018 et Azaiez et al., 2020). The spatial distribution of the concentration time is the average of 
these 4 formulas. According to the map of concentration time (Figure 17), runoff occurs in a very short time span between 30 and 50 minutes in El mensek, Sharafia, Dhabab and Rawdha districts.

It is the hypsometric conditions and the collected shape of their watersheds that are at the origin of the rapid response of some of them. Concentration time slows down to 3 hours and 20 minutes in the El Massif and Noomène sectors which are of rural characteristics. On the other hand, the concentration time remains underestimated compared to the actual concentration time. Indeed all these formulas do not take into consideration the nature of the soil, which is largely clayey and impermeable, nor the state of the pipeline set up for the evacuation of rainwater.

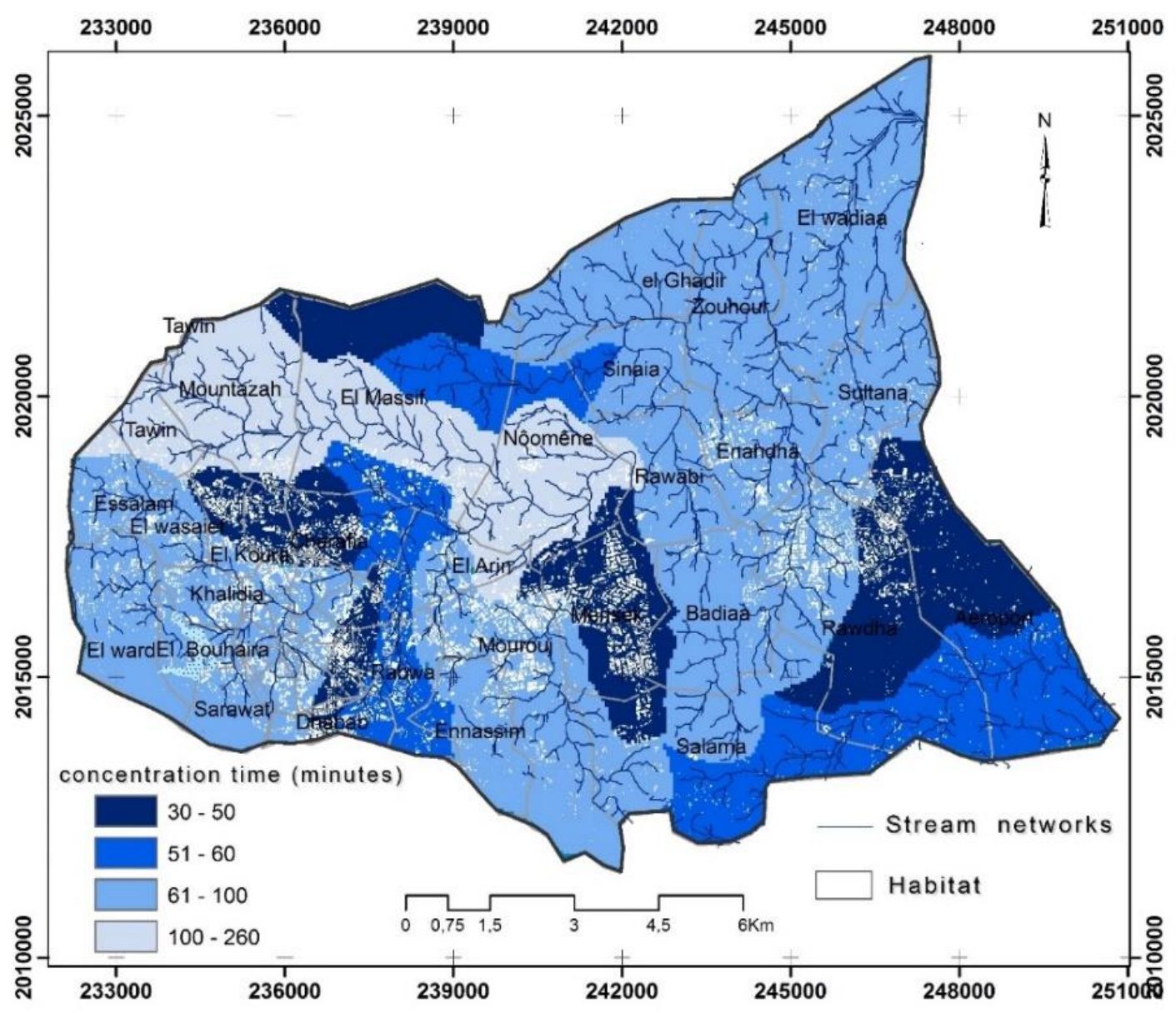

Figure 17. Map of concentration time by district in the city of Abha

(Source: data processing results from the land use map, 2019 and hypsometric data)

Therefore, the wetting of the soil on the one hand and the clogging of the sewers and poor maintenance on the other hand can lead to a more accelerated concentration of runoff water. On the contrary, when a potentially torrential shower occurs during a dry season, soils and slopes are intensely dehydrated and due to the presence of clay constituents shrinkage cracks form as a result of the retraction of the clays. These macro-cracks will constitute proliferation zones for rainwater to infiltrate to the depths.

Thus a notable decrease in the height of the runoff water layer takes place (Inoubli, 2014 et Quefféléan and Unanoa, 2018. This observation indicates that the runoff water layer during summer showers will be much lower than that recorded during heavy rainfall in the wet and cold season. In this case, the whole quantity of precipitated water will form the runoff water layer, due to the total wetting of the soil. As a result of this behaviour of the clay soil, a runoff layer occurs, accelerates and finally accumulates at the outlet in a very short span of time.

\section{Estimating Runoff Water Layer during Exceptional Rainfall Events in the City of Abha}

The objective here is not only to spatially limit the sectors generating runoff, but also to estimate the height of the runoff water according to the daily rainfall amounts recorded between 1978 and 2018. Thus, an attempt has been made to estimate the runoff water layer associated with the rainfall events that caused catastrophic flooding during these three 
decades through a cartographic modeling approach. During the modeling, the interest is mainly focused on the potentially torrential rains recorded in the city of Abha. Four rainfall events of different intensity were selected, (279 mm in 1996 and $116 \mathrm{~mm}$ in 2017).

The Almahala area constitutes a permanently flood-prone sector, especially the convergence points of several streams coming from uneven areas with a remarkable flow. In the second place come the districts El Mensek, El Mourouj, Charafia and Durat el Mensek where the water height can quickly reach $1.49 \mathrm{~m}$ and even more in the areas of saddles and at the level of the confluence of rivers. This increase is caused by the combined effect of several parameters: heavy rains, very high runoff coefficient and very short concentration time. This indicator is defined through the runoff coefficient and total daily rainfall.

It is also affected by the increased soil sealing that has accompanied urban sprawl. This runoff can occur even in agricultural areas and on very gentle slopes with predominantly clay soils of reduced permeability (Photos 1 and 2). The clayey spectrum, which marks the soils of the middle course of Wadi Abha, are mostly formed by smectite and illite and partly by kaolinite and other newly formed inter-layers (Ben Menaa el Amri. A, 2007).

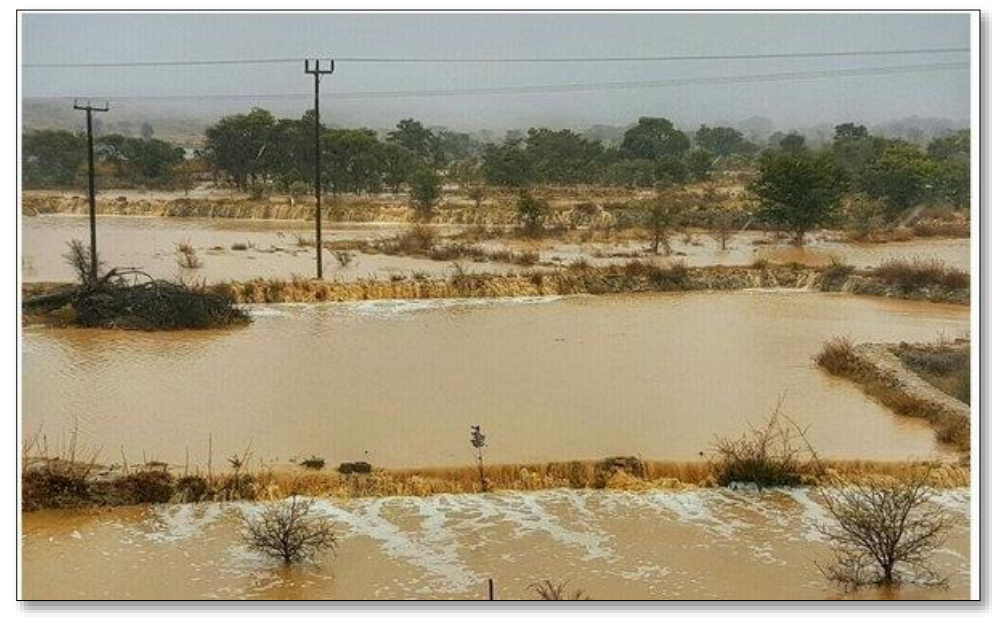

Photo 1. the flooded section of Wadi Abha in the El Arine region during the 2017 floods (Source: Photo archive, Arab News, 2017)

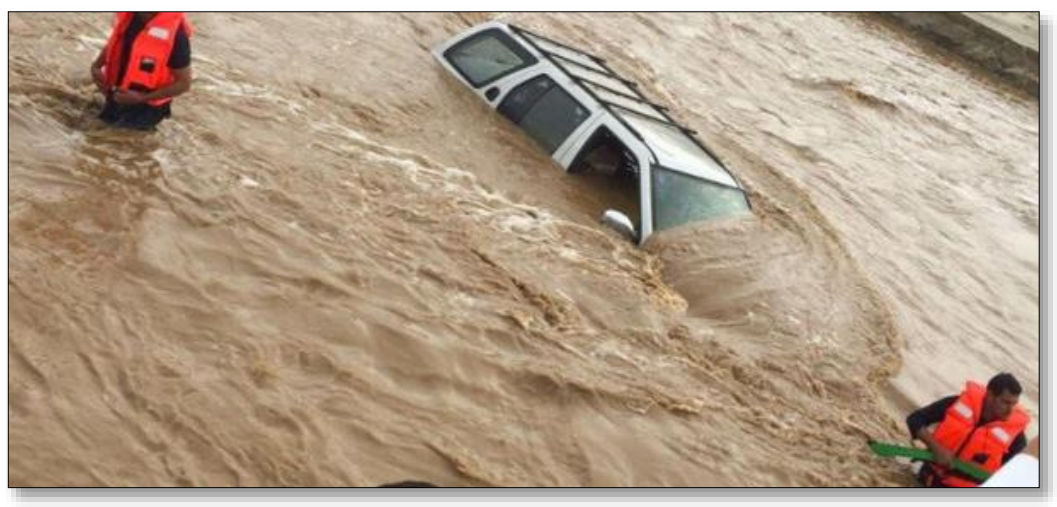

Photo 2. the flood in El Mensek district (Source: Photo archive, Arab News, 2017)

\section{Flood Hazard Map}

The notion of hazard comes from a natural viewpoint, whereas risk is an interface concept that takes on a social dimension but is closely linked to a physical reality physique (Hatim et al., 2014 ; Helga, 2014; Liping et al.; 2015 ; Faddaz, 2016 et Abdelkarim, 2019). In the first stage, an attempt was made to delimit risk zones through topography alone. Thus, it was found that the low areas with very gentle slopes, saddle zones and the outlet constitute the potentially flood-prone areas (Figure 18). 
On the other hand, the phenomenon of flooding is not solely attributable to topography, because rising water in itself does not systematically lead to flooding, but considering the complexity of the causes and acting factors, a rise in water levels can turn into a true flood disaster. Thus, through the superimposition of the different layers of factors involved in the floods, (includes slope value, land use and rainfall value), it was possible to generate the flood hazard map specific to the study area. This cartography consists in determining the scope of the flood prone perimeters according to the factors and processes that influence the functioning rhythm of the hydrosystem and the different human activities and developments likely to further increase the flood risk given the forcing of rains considered torrential, as confirmed by the trend line. (Figure 20)

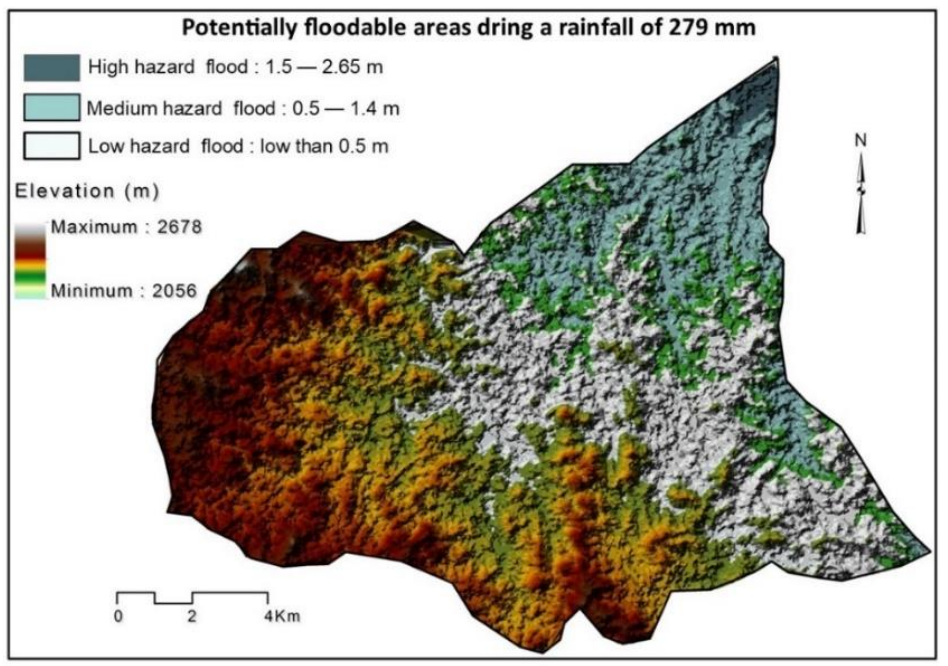

Figure 18. Potentially floodable areas defined by topography.

(Source: processing results of an SRTM image under Arc GIS)

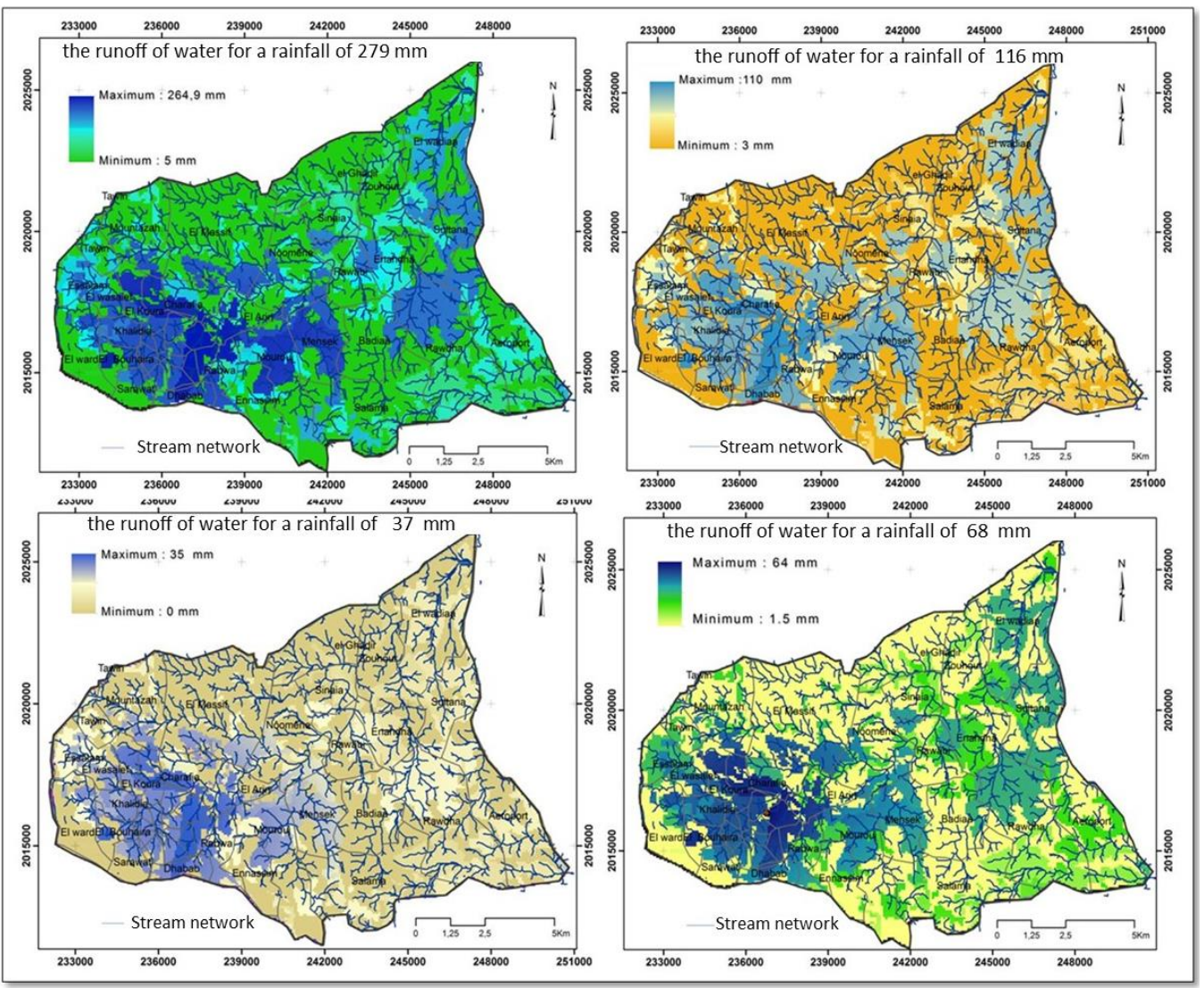


Figure 19. Modeling of the runoff of water for some rainfall events accompanied by flooding in the city of Abha (1996, 2016 and 2017) (Source: Data from the General Authority for Meteorology and Environmental Protection 1978 -2018)

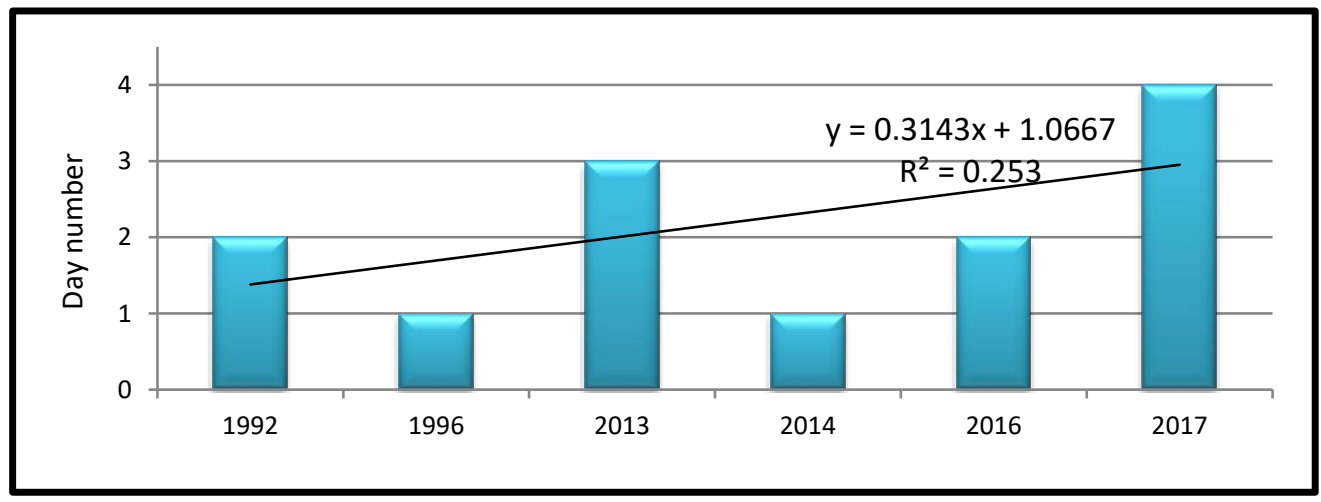

Figure 20. The trend of potentially torrential rains between 1978 and 2018

(Source: Data from the General Authority for Meteorology and Environmental Protection 1978 -2018)

The highest hazard in the city of Abha corresponds to the lowest compartments with very low slopes, high runoff coefficient, short concentration time and high residential density. These areas are located on either side of the main river of Wadi Abha. The risk is all the more considerable for the habitats built in the major bed and in saddle areas. The habitats best protected against the risk of flooding are those located on the slopes and flat-topped hills (Figure 21).

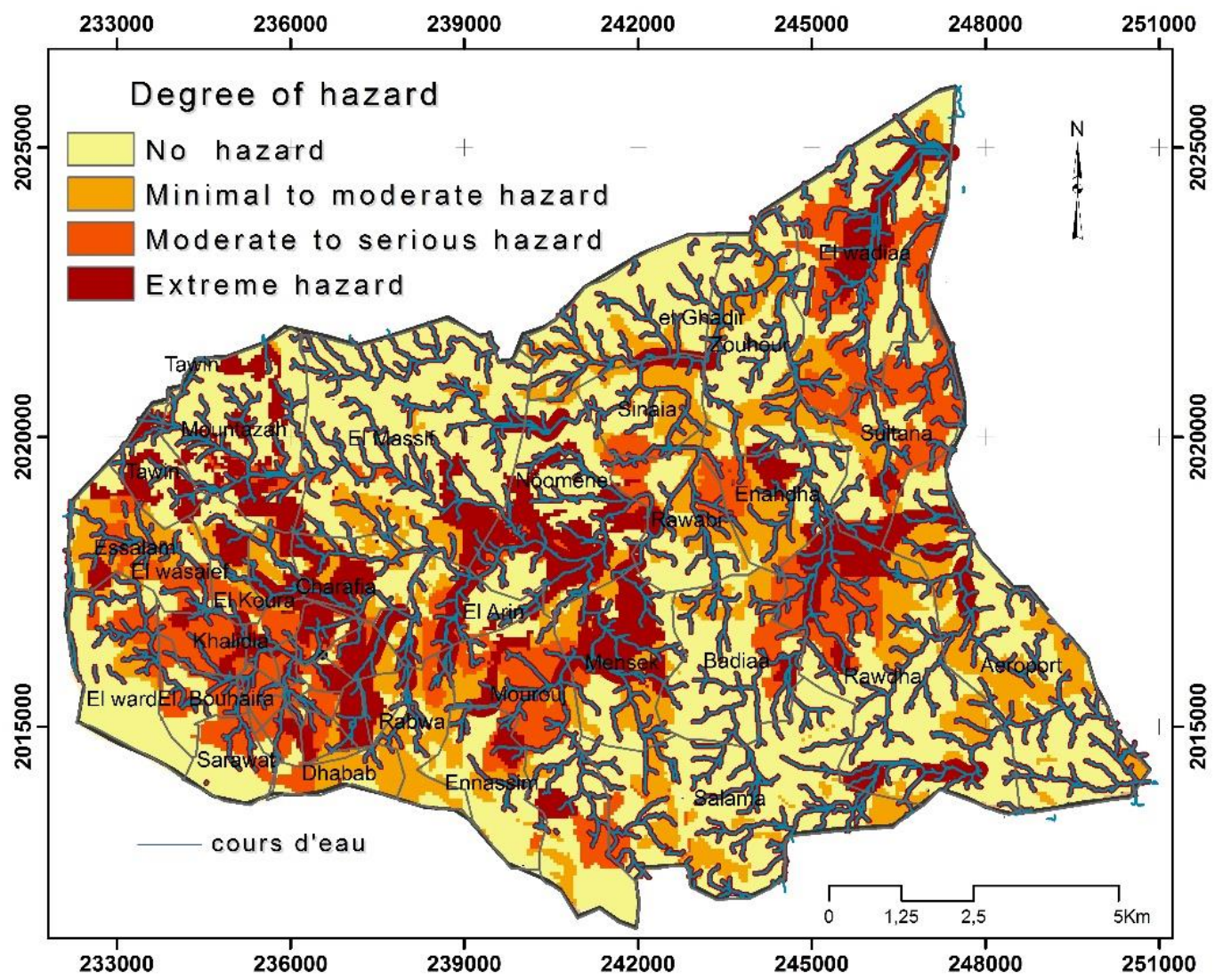

Figure 21. Flood hazard map (Source: data processing results from the land cover map, 2019 and hypsometric data and the concentration time map) 


\section{Discussion and results}

Flooding in the city of Abha represents a hazardous phenomenon, and its management requires a good knowledge of the causes, contributing factors and areas at risk, as well as the processes that control the behavior of the hydro-systems and the human activities that are related to them. Floods are generally attributed exclusively to extreme rainfall events, but not everything should be blamed on torrential rains. The flood situation is sometimes a latent fact given the topographical contrast and imprudent human installations, along with other factors of a technical nature, such as the effects of counterslope, sewer back-up and dam release.

This study was an opportunity to map the areas that are prone to flooding and provide results that will help to design the necessary intervention measures and classification of the different sectors according to the degree of risk through a comparative test between some empirical models, and a rational method and various processes of floods. The results of the study may serve to adapt prevention and intervention programs able to promote an effective management and urban planning strategies that ensure effective governance of urban space while respecting the environmental tolerance threshold, taking into account the behavior of each sub-basin.

To ensure effective risk management, flooding should be taken as a basic feature of the city of Abha which is located at the convergence of several watercourses, and not as a short-term intervention imposed by a given rainfall event. The action that must be taken is to prepare the city to adapt to the risk of flooding and to increase its resilience by managing water as close as possible to the natural water cycle (Helga et al, 2014 and El Qhtani, 2019). State intervention will be easier and more targeted if the flood control systems are set up according to different scenarios, after having established a good archive and knowledge of the hydro-meteorological situations that accompanied the most catastrophic floods in the city.

It is necessary to look for a management itinerary to take preventive measures based on the return period for each rainfall event (Helga et al, 2014 et Abdelkarim, 2019). The applied statistical method has provided an idea of the return period of the frequent low-risk floods with an occurrence of 2 to 5 years and the so-called major floods with a n occurrence of 50 to 100 years, which are considered among the most serious and catastrophic ones (Figure 22). Generally, the areas threatened by the longest floods are the lower, gently sloping areas marked by streams of weak flow (Prakash, 2004, Abdelkarim, 2019).

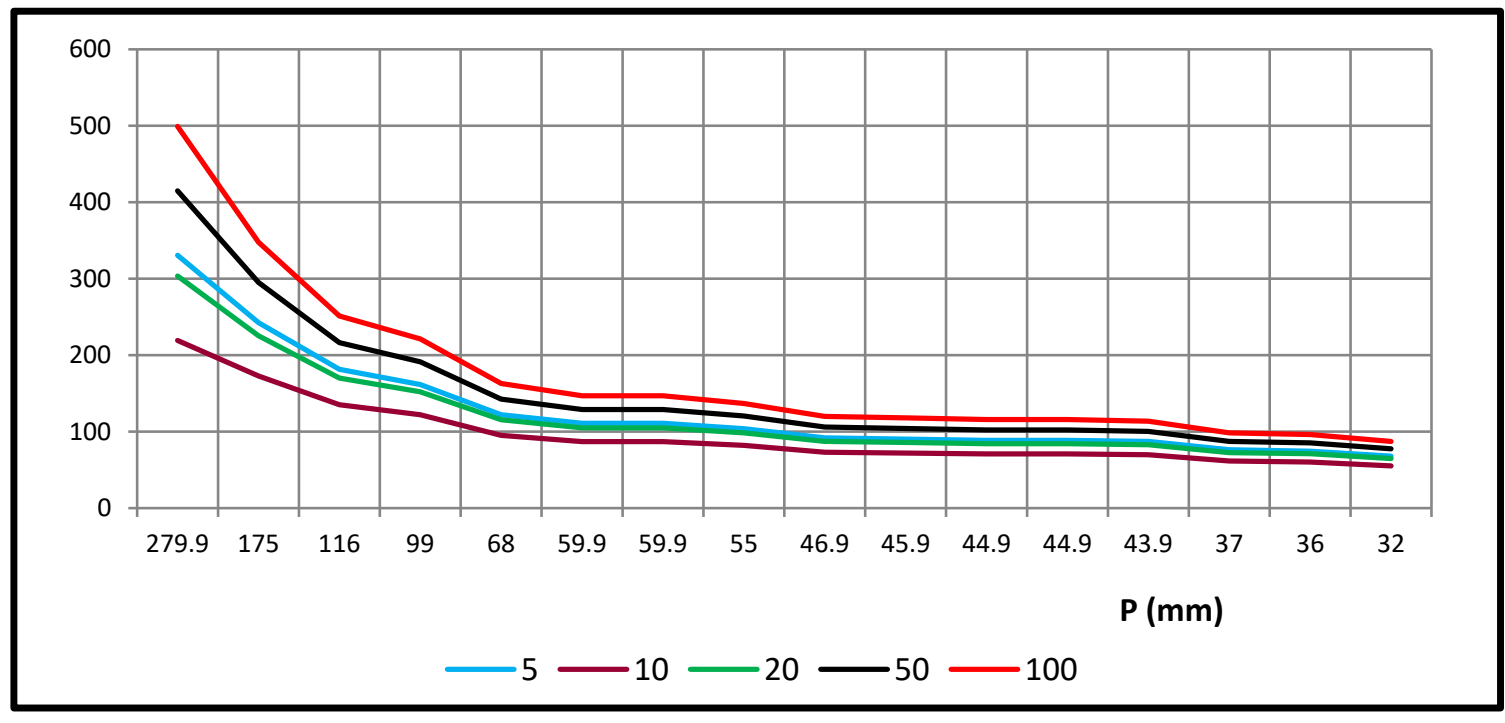

Figure 22. Return period of potentially torrential rains (Source: Data from the General Authority for Meteorology and Environmental Protection 1978 -2018)

In contrast, districts located in areas with slightly sloping topography record the fastest and most severe floods caused by high-flow streams. The most frequent floods in the city of Abha are average floods with daily rainfall between $32 \mathrm{~mm}$ and $116 \mathrm{~mm}$ (Figure 22). More than $80 \%$ of daily rainfall during the study period was between $32 \mathrm{~mm}$ and $116 \mathrm{~mm}$ and was potentially torrential. Above this amount, rainfall becomes rare and of low probability (Figure 23).

However, these results and the observation on the return period of torrential rains remain very close to those calculated in the watershed of Wadi Bayadh in Jizan (Abdelkarim, 2019), in the city of Ryadh and in the Mediterranean region (Raymond et al., 2016). In the two cities, Mecca and Jiddah, the floods are rather of topographical nature (Blehed, 1986 ; Jade, 19668; Qari, 2009 and Raymond et al., 2016; Youssef et al, 2016), in Ryadh city (Hatim et al., 2016 et Faddaz et al., 
2016), but also amplified by meteorological situations marked by a deep and rapid convection.

Flooding is an event that is prepared from upstream to downstream (Helga et al, 2014 and Raymond et al., 2016). Indeed, all the slopes that surround the city of Abha are largely arranged in agricultural terraces delimited by retaining walls or dry-stone bunds and are at the origin of a resistance that opposes runoff. This roughness coefficient conditions a loss of load on the watercourses and reduces the speed of flow in the water channels, especially those with a riparian vegetation cover capable of creating an arching effect and regulates the flow of water (Laborde, 2000). But the situation changes in the middle of residential areas where the watercourses are carried in open channels made of artificial concrete where, with the occurrence of torrential floods, the flow rises very quickly and an overflow occurs very far from the minor bed.

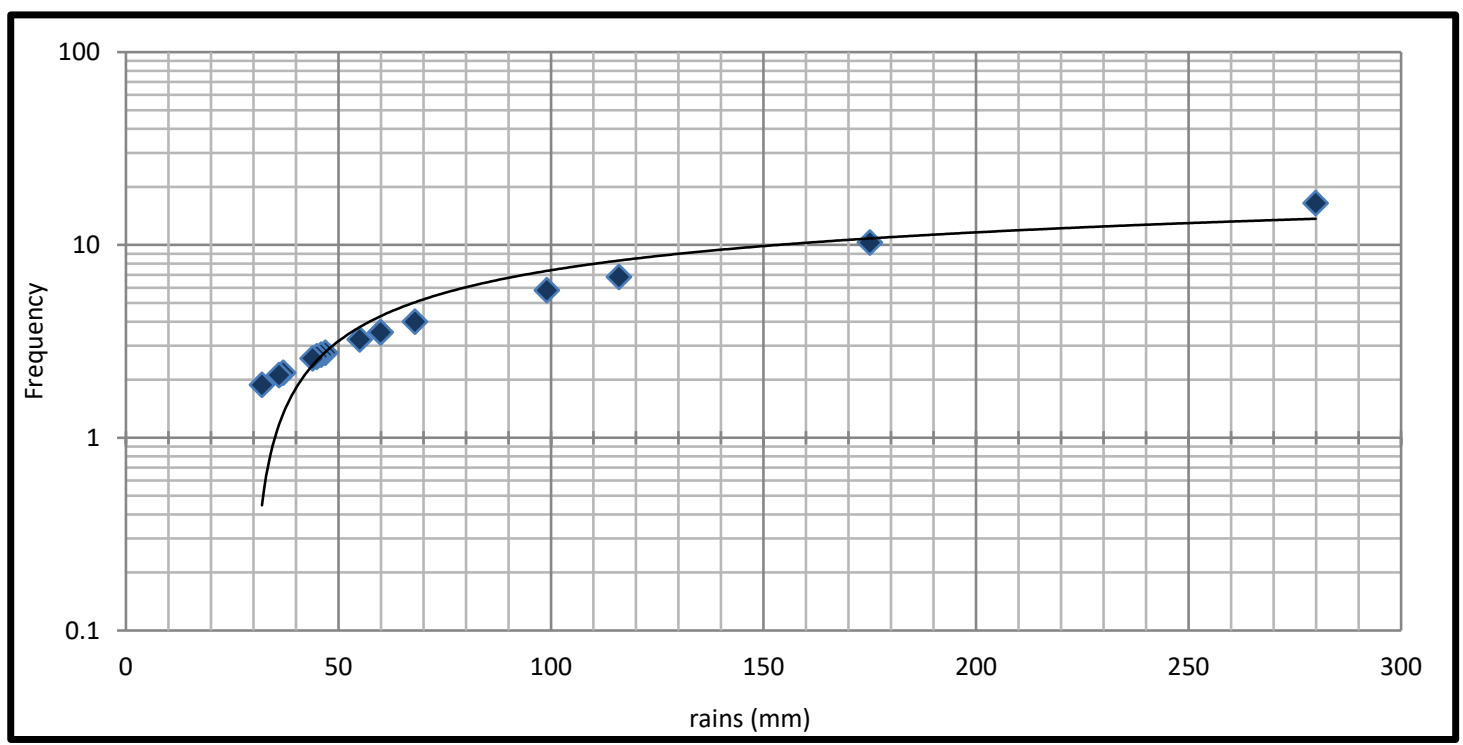

Figure 23. The frequency of potentially torrential rains between 1978 and 2018

(Source: Data from the General Authority for Meteorology and Environmental Protection 1978 -2018)

\section{Conclusion}

After examining the various factors contributing to the flooding in the city of Abha through a statistical and cartographic modeling method, it turned out that some districts of the city of Abha are at risk of flooding almost every 5 years, in particular the two districts of El Mensek and El Mourouj. Other districts (Charafia, Soltana el Badiaa ...) are affected by occasional floods during very exceptional rainfall events. In order to face this problem, an appropriate approach to rainwater management needs to be developed based on an experimental study of the urban water cycle. The need to rethink the urban phenomenon in order to make the best use of the available space remains essential to guarantee a sufficiently permeable urban structure. Thus, the inevitable increase in the density of the residential areas must be followed by the installation of detention basins in order to reduce the amount of run-off water once the streams reach their peak flows, especially for sectors under threat of potentially recurrent flooding. This water will then be released progressively at regulated flows into the water system.

Funding: All authors are funded through the general research project from the Deanship of Scientific Research at King Khalid University under research grant number (RGP.1/241/1442).

\section{Acknowledgments}

The authors extend their appreciation to the Deanship of Scientific Research at King Khalid University for funding this work through General Research Project under grant number (RGP.1/241/1442)

\section{References}

Abdelkarim, A. (2019). Flood Hazards of the Jizan-Abha Highway, Kingdom of Saudi Arabia by Integrating SpatialBased Hydrologic and Hydrodynamic Modeling. Global Journal of Engineering Science and Research Management, 19 (4), 92. https://doi.org/10.3390/s19051024

Abdelkarim, A., Ahmed, F. D., \& Gaber. (2019). Flood Risk Assessment of the Wadi Nu'man Basin, Mecca, Saudi Arabia (During the Period, 1988-2019) Based on the Integration of Geomatics and Hydraulic Modeling: A Case Study. Water, 
11, 1887. https://doi.org/10.3390/w11091887

Abhas, K. J., Bloch, R., \& Lamond, J. (2012). Cities and Flooding: A Guide to Integrated Urban Flood Risk Management for the 21st Century, $638 \mathrm{p}$.

Alamri, Y. A. (2011). Rains and floods in Saudi Arabia. Crying of the sky or of the people? Saudi medical journal, 32(3), 311-313.

Al-Ghamdi, K. A., Elzahrany, R. A., Mirza, M. N., \& Dawod, G. M. (2012). Impacts of urban growth on flood hazards in Makkah City, Saudi Arabia. International Journal of Water Resources and Environmental Engineering, 4(2), 23-34.

AL-Jerash, M. (1992). Climatic regions in Saudi Arabia: A comparative application of cluster analysis and principal components analysis. Research papers in Geography. $N^{\circ}$ 13. King Saud University. Riyadh. Kingdom of Saudi Arabia. Assessment of the Expected.

Almeidai, I. K., Kaufmann, A., Almeidai, J. A., Anache, A., Steffen, J. L., \& Sobrinho, T. A. (2014). Estimation on time of concentration of overland flow in watersheds: a review. São Paulo, UNESP, Geociências, 33(4), 661-671.

Al Saud, M. (2015). Flood Control Management for the City and Surroundings of Jeddah, Saudi Arabia, The Springer Natural Hazards, 177. https://doi.org/10.1007/978-94-017-9661-3

Ameur, F. (2016). Floods in Jeddah, Saudi Arabia: Unusual Phenomenon and Huge Losses. What Prognoses, 6E3S We b of Conference se3sconf/201FLOODrisk 2016 - 3rd European Conference on Flood Risk Management 70704019. https://doi.org/10.1051/04019 (2016),

Ansar, A. (2004). Typologie des pluies moyennes annuelles en Algérie du nord (1931.1955). Bulletin de la société de géographie d'Egypte. Tome LXXVII. 77.

Ashammari, E. Z. Ruslan R. Bint Abdurrahman, A., \& Abdulkadir, M. (2020). Flash flood causes in Ha'il city kingdom of Saudi Arabia using Remote Sensing data and GIS. Journal of Critical Reviews, 7(1), 144-153.

Azaiez, N. (2016). La dynamique géomorphologique actuelle dans le bassin versant de l'oued el Meleh Bou el Ajraf (Tunisie Centre orientale) : Cartographie et essai de quantification de l'érosion hydrique. Thèse de Doctorat, Université de Tunis I, 271.

Azaiez, N. Ansar, A. Baazaoui, N., \& Qhtani, N. (2020). Assessment of Soil Loss in the Mirabah Basin: An Overview of the Potential of Agricultural Terraces as Ancestral Practices (Saudi Arabia). Open Journal of Soil Science, 10, 159-180. https://doi.org/10.4236/ojss.2020.105008

Blehed, A. S. (1986). Rainfall Distribution and variability in Saudi Arabia. J. coll. Arts, King Saud University, 13, 125140 .

Ben Menaa el Amri, A. (2007). Pedological characteristics of the soil in Wadi Bisha, master memory, King Saoud University, 171.

El Qahtani, S. et al. (2019). Climate Change and its Effect on Temperature and Precipitation. Institute for Research and Consulting Studies and Agriculture and Water Authority, 110, (in Arabic).

Faddaz, E. Jamal-Uddeen, S., \& Elhassan, E. (2016). Flood hazards in an urbanizing watershed in Riyadh, Saudi Arabia. Geomatics, Natural Hazards and Risk, 7(2), 702720, 701-720.

Giandotti, M. (1934). Previsione delle piene e delle magre dei corsi d'acqua, memorie e studi idrografici,304 pubbl. 2 del servizio idrografico italiano: Rome, italy, $8,8(2)$.

Giandotti, M. (1940). Previsione empirica delle piene in base alle precipitazioni meteoriche, alle caratteristiche fisiche e morfologiche dei bacini; Applicazione del metodo ad alcuni bacini dell'Appennino Ligure. Memorie e Studi Idrografici, v. 10 , p. $5-13$.

Giret , A. (2007). Géographie de l'écoulement fluvial, Harmattan, 193.

Gomaa. D, Mirza, M. N., \& Al-Ghamidi. Kh. (2011). GIS-Based Spatial Mapping of Flash Flood Hazard in Makkah City, Saudi Arabia. Journal of Geographic Information System, 3, 217-223. https://doi.org/10.4236/jgis.2011.33019 Published Online July 2011 (http://www.SciRP.org/journal/jgis)

Hatim, O., Sharif, Y., Farhan, H., Al-juaidiz, A., Al-Othmanx, I., Al-dousary. Scarwell, H. J., Schmitt, G., \& Salvador, P. G. (2014). Urbanisme et inondation : outils de réconciliation et de valorisation, Presses Univ. Septentrion.

Inoubli, N., Raclot, D., Habaieb, H., Moussa, R., \& LE Bissonnais, Y. (2014). Ruissellement et érosion dans un petit bassin marneux agricole de Tunisie, Confrence Paper, 3ème Colloque International Eau-Climat 2014 : REGARDS CROISES NORD SUD, pp 9. Jade Kerbe, 1987, Les caractéristiques dynamiques du climat de l'Arabie, Revue 
géographique de l'Est 27(3):151-169 · January 1987. https://doi.org/10.3406/rgest.1987.1628

Kirpich, Z. (1940). Time of concentration of small agricultural watersheds. Civil Engineering, 10(6), 362.

Laborde, J. P. (2009). Eléments d'hydrologie de surface, Polytech-Nice-Sophia, 192.

Ledraa, T., \& Al-Ghamidi, A. M. (2020). Planning and Management Issues and Challenges of Flash Flooding Disasters in Saudi Arabia: The Case of Riyadh City. Journal of Architecture and Planning, 32(1), 155-171. doi:10.33948/JAPKSU-32-1-6, p 155-171.

Liping, D., Matthew F., McCabe, Stenchikov, M. C., Jason, G., Evans, P., \& Kucera, A. (2015). Simulation of FlashFlood-Producing Storm Events in Saudi Arabia Using the Weather Research and Forecasting Model. Journal of Hydrometeorology, 16, 615-630. http://dx.doi.org/10.1175/JHM-D-14- 0126.s1.

Qari, M. H. (2009). Geomorphology of Jeddah Governate, with emphasis on drainage systems JKAU. Earth Sci., 20(1), 93-116.

Quefféléan, Y., \& Unanoa, S. (2018). Estimation des gradients et temps de montée des crues rapides observées sur les Alpes et les Pyrenees, Conference Paper, Conference: Colloque SHF "De la prévision des crues à la gestion de crise" - 14 au 16 novembre 2018 Avignon, At Avignon - France.

Peguy, Ch. (1970). Précis de climatologie, Paris, Masson, 468 p.

Prakash, A. (2004). Water Ressources Engineering Handbook of Essential Methods and Design. Americain Society of Civil Engineers, 719.

Raymond, F., Ullmann, A., \& Camberlin, P. (2016). Précipitations intenses sur le Bassin Méditerranéen: quelles tendances entre 1950 et 2013? La revue Cybergeo: European Journal of Geography, 12. https://doi.org/10.4000/cybergeo.27410.

Shwehdi, M. H. (2006). Reliable Maps of LightningThunderstorms for Saudi Arabia. IEEE TRANSACTIONS ON POWER DELIVERY, 21(3), 1571-1577.

Subyani, A. (2010). Hydrologic behavior and flood probability for selected arid basins in Makkah area, western Saudi Arabia. Arabian Journal of Geosciences. http://dx.doi.org/10.1007/s12517-009-0098-1

Subyani, A. M., Qari, M. H., Matsah, M. E., Al-Modayan, A. A., \& Al-Ahmadi, F. S. (2009). Utilizing remote sensing and GIS techniques to reduce hydrological and environmental hazards in some wadis, Western Saudi Arabia (JeddahYanbu). King Abdulaziz City for Sciences and Technology, Project No. APR 25/101.

Youssef, M. A., Sefry, S. A., Pradhan, B., \& Abu Alfadail, E. (2016). Analysis on causes of flash flood in Jeddah city (Kingdom of Saudi Arabia) of 2009 and 2011 using multi-sensor remote sensing data and GIS. Geomatics, Natural Hazards and Risk, 7(3), 1018-1042. http://dx.doi.org/10.1080/19475705.2015.1012750, pp, 1018 - 1042.

\section{Copyrights}

Copyright for this article is retained by the author(s), with first publication rights granted to the journal.

This is an open-access article distributed under the terms and conditions of the Creative Commons Attribution license (http://creativecommons.org/licenses/by/4.0/). 